\title{
Microbial Community Response to Simulated Petroleum Seepage in Caspian Sea Sediments
}

\author{
Marion H. Stagars ${ }^{1}$, Sonakshi Mishra ${ }^{2}$, Tina Treude ${ }^{2,3,4}$, Rudolf Amann ${ }^{1}$ and \\ Katrin Knittel ${ }^{\text {* }}$
}

${ }^{1}$ Department of Molecular Ecology, Max Planck Institute for Marine Microbiology, Bremen, Germany, ${ }^{2}$ Department of Marine Biogeochemistry, GEOMAR - Helmholtz Centre for Ocean Research Kiel, Kiel, Germany, ${ }^{3}$ Department of Earth, Planetary and Space Sciences, University of California, Los Angeles, Los Angeles, CA, USA, ${ }^{4}$ Department of Atmospheric and Oceanic Sciences, University of California, Los Angeles, Los Angeles, CA, USA

\section{OPEN ACCESS}

Edited by:

Télesphore Sime-Ngando, Centre National de la Recherche Scientifique (CNRS), France

Reviewed by:

Zongze Shao,

State Oceanic Administration, China Alejandro Acosta-Gonzalez, Universidad de La Sabana, Colombia

*Correspondence: Katrin Knittel

kknitte@@mpi-bremen.de

Specialty section: This article was submitted to Aquatic Microbiology, a section of the journal Frontiers in Microbiology

Received: 15 October 2016 Accepted: 12 April 2017 Published: 28 April 2017

Citation:

Stagars MH, Mishra S, Treude T, Amann R and Knittel K (2017) Microbial Community Response to Simulated Petroleum Seepage

in Caspian Sea Sediments.

Front. Microbiol. 8:764. doi: 10.3389/fmicb.2017.00764
Anaerobic microbial hydrocarbon degradation is a major biogeochemical process at marine seeps. Here we studied the response of the microbial community to petroleum seepage simulated for 190 days in a sediment core from the Caspian Sea using a sediment-oil-flow-through (SOFT) system. Untreated (without simulated petroleum seepage) and SOFT sediment microbial communities shared $43 \%$ bacterial genuslevel 16S rRNA-based operational taxonomic units $\left(\mathrm{OTU}_{0.945}\right)$ but shared only $23 \%$ archaeal $\mathrm{OTU}_{0.945}$. The community differed significantly between sediment layers. The detection of fourfold higher deltaproteobacterial cell numbers in SOFT than in untreated sediment at depths characterized by highest sulfate reduction rates and strongest decrease of gaseous and mid-chain alkane concentrations indicated a specific response of hydrocarbon-degrading Deltaproteobacteria. Based on an increase in specific CARD-FISH cell numbers, we suggest the following groups of sulfate-reducing bacteria to be likely responsible for the observed decrease in aliphatic and aromatic hydrocarbon concentration in SOFT sediments: clade SCA1 for propane and butane degradation, clade LCA2 for mid- to long-chain alkane degradation, clade Cyhx for cycloalkanes, pentane and hexane degradation, and relatives of Desulfobacula for toluene degradation. Highest numbers of archaea of the genus Methanosarcina were found in the methanogenic zone of the SOFT core where we detected preferential degradation of long-chain hydrocarbons. Sequencing of mas $D$, a marker gene for alkane degradation encoding (1-methylalkyl)succinate synthase, revealed a low diversity in SOFT sediment with two abundant species-level MasD OTU 0.96 .

Keywords: hydrocarbon degradation, alkyl succinate synthase, MasD, sulfate reduction, microbial diversity, crude oil

\section{INTRODUCTION}

Petroleum mainly consists of aliphatic hydrocarbons (alkanes), naphthenes, aromatics, asphaltenes, and other compounds in varying composition depending on where and how it was formed. A large and diverse number of microorganisms, including bacteria, archaea, and fungi, have evolved the ability to utilize these hydrocarbons as sources of food and energy for growth under either oxic or anoxic conditions (Grossi et al., 2008; Heider and Schühle, 2013).

Contaminations of an ecosystem with hydrocarbons as observed, e.g., after the Deepwater Horizon disaster in the Gulf of Mexico (Atlas and Hazen, 2011; Kimes et al., 2013, 2014), have important consequences on the autochthonous microbial communities, which suffer drastic 
changes in structure and function. In the oxic water column the majority of oil is degraded by aerobic microbes, while oil from "natural spills" at hydrocarbon seeps is mainly degraded by anaerobic microbes living in benthic environments (Head et al., 2003; Jones et al., 2008). Using sulfate, nitrate, manganese, or ferric iron as electron acceptors anaerobic enrichment cultures were established from marine seep sediments, oil reservoirs and petroleum polluted sites (e.g., Kniemeyer et al., 2007; Mbadinga et al., 2012; Acosta-González et al., 2013; Jaekel et al., 2013; Bian et al., 2015) and several isolates have been obtained (Figure 1). Furthermore, hydrocarbon-degrading syntrophic enrichment cultures have been established under methanogenic conditions (e.g., Zengler et al., 1999; Chang et al., 2006; Berdugo-Clavijo and Gieg, 2014; Embree et al., 2014). Responsible strains can degrade only a narrow range of hydrocarbon sources and belong to the phyla Proteobacteria and Firmicutes within the domain Bacteria or to Euryarchaeota within the domain Archaea. A common way of anaerobic non-methane alkane activation is its addition across the double bond of fumarate to form alkyl-substituted succinates, a step catalyzed by a glycyl radical enzyme, 1-methyl alkyl succinate synthase [Mas, Grundmann et al., 2008; Rabus et al., 2016; also known as alkylsuccinate synthase (Ass, Callaghan et al., 2008)]. Other known mechanisms for non-methane alkane activation include anaerobic hydroxylation followed by carboxylation and the oxygen-independent hydroxylation (reviewed in Callaghan, 2013). Most cultivated anaerobic alkane degraders activate alkanes via fumarate addition. Thus, the gene encoding the catalytic subunit of the responsible enzyme Mas

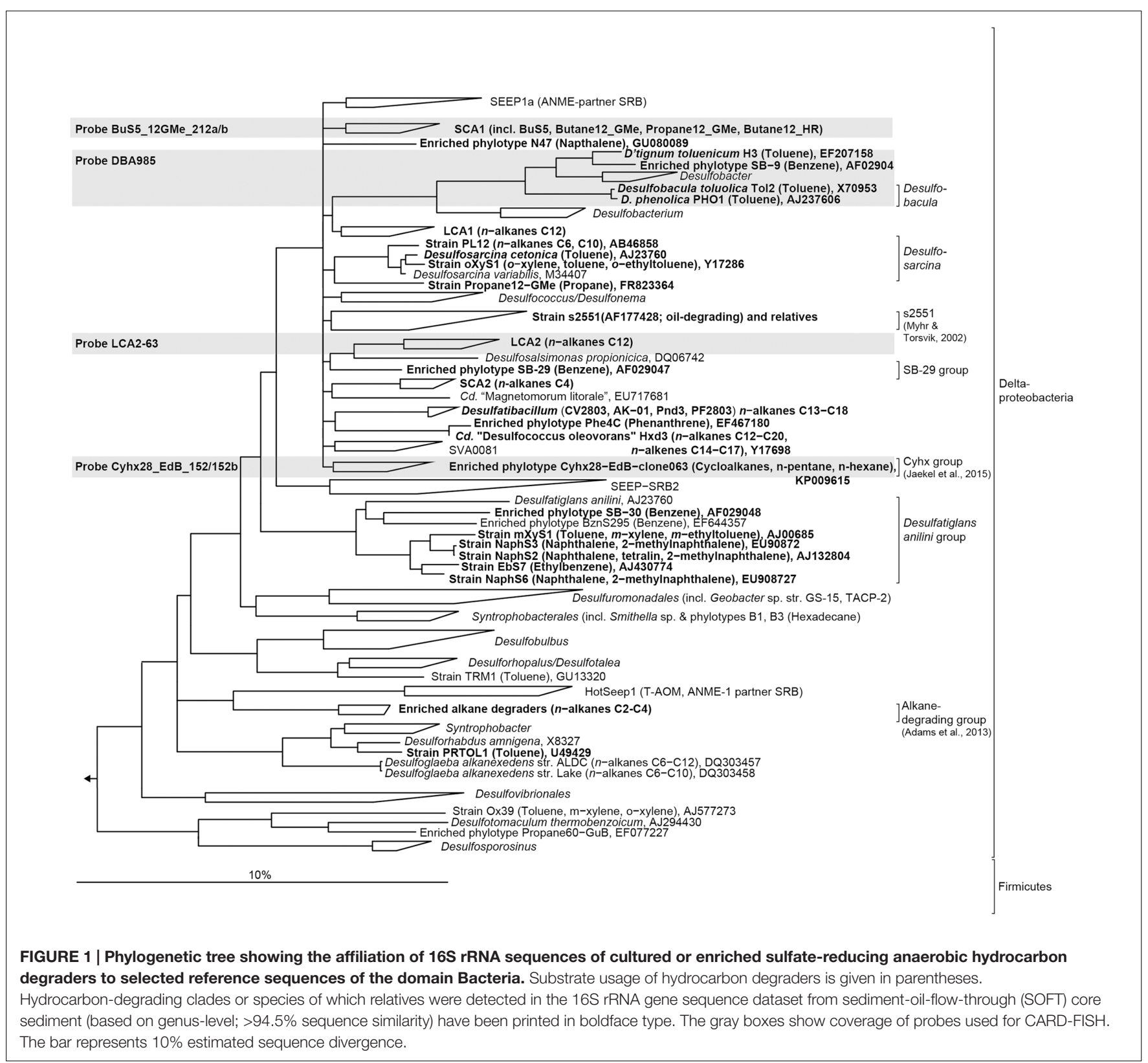


$(\operatorname{mas} D)$ serves as relevant genetic marker and its study allows a cultivation-independent survey of the diversity and distribution of alkane-degrading communities in any anoxic hydrocarbonimpacted environment.

The fate of oil in the marine environment is subjected to microbial activity, thus altering the oil's composition. The rate of microbial degradation depends on several environmental factors like nutrients, salinity, and availability of terminal electron acceptors, composition of petroleum, temperature and pressure (Atlas, 1981; Leahy and Colwell, 1990). Only few studies investigated anaerobic hydrocarbon degradation under close-toin situ conditions and most of these studies have focused either on one or few selected hydrocarbons (Mbadinga et al., 2011; Jaekel et al., 2013, 2015; Johnson et al., 2015; Musat, 2015). Thus, the aim of this study was to follow the response of the benthic microbial community to simulated petroleum seepage in a marine sediment core. The Caspian Sea was selected as study site because it is one of the oldest petroleum-producing regions in the world with huge oil and gas reserves (Effimoff, 2000). Anthropogenic reasons such as offshore drilling, oil refineries and pipeline constructions as well as natural reasons such as hydrocarbon release from mud volcanoes (Akper, 2012) have led to pollution of Caspian Sea (Karpinsky, 1992; Dumont, 1995). Pollutants accumulate and are partly trapped, e.g., in surface sediments. So far only a few studies have studied petroleumdegrading microbial communities in sediments from the Caspian Sea (Hassanshahian et al., 2010, 2012; Hassanshahian, 2014; Mahmoudi et al., 2015).

In the accompanying study by Mishra et al. (this issue) a sediment-oil-flow-through (SOFT) system was established that simulated petroleum seepage-like conditions. In this SOFT system, whole round sediment cores from the Caspian Sea are supplied with petroleum flow from bottom to top (simulating a seep situation) and artificial oxic seawater from ventilated supernatant. Using these sediments from the SOFT experiment (Mishra et al., this issue) we here report the microbial 16S rRNA gene diversity after 190 days of simulated petroleum seepage. In comparison, untreated sediments were analyzed. Furthermore, the anaerobic alkane-degrading community was characterized based on mas $D$ gene diversity. We hypothesize that individual taxa respond specifically to simulated petroleum seepage by an increase of their cell numbers resulting in a change of community composition. We further hypothesize that this specific cell increase is vertically structured according to sequential petroleum-degradation. To address these hypotheses specific cell numbers of selected hydrocarbon-degrading taxa in SOFT and untreated sediments were determined by CARD-FISH, and molecular data obtained in this study were correlated with the biogeochemical and petroleum degradation data obtained by Mishra et al. (this issue).

\section{MATERIALS AND METHODS}

\section{Study Site and SOFT System}

The study site Baku Bay is located in the SW Caspian Sea near Baku, Azerbaijan (N 39 59.548, E 49 28.775, Supplementary
Figure S1). In the past, the Caspian Sea was, as remnant of the Paratethys Sea, connected to oceans, but has become landlocked about five million years ago. There is large influx of freshwater by numerous rivers that drain into the Caspian Sea, thus the salinity is only about one-third of that of seawater $(1.3 \%$, Millero and Chetirkin, 1980). In November 2012, several sediment cores (large cores: $30 \mathrm{~cm}$ long, $6 \mathrm{~cm}$ in diameter; small cores: $30 \mathrm{~cm}$ long, $2.6 \mathrm{~cm}$ in diameter) were collected from a coastal area at a water depth of $\sim 60 \mathrm{~cm}$. Cores were directly sealed and stored at $10^{\circ} \mathrm{C}$ in the dark for 3 months until three large and two small cores were processed as reference (referred to as "untreated sediment") upon arrival at GEOMAR, Germany. Cores were used for sediment pore water analyses (1 large core), sediment solid phase and molecular analyses (1 large core), and sulfate reduction activity ( 2 small cores; for details see Mishra et al., this issue). The third large core was stored at $0^{\circ} \mathrm{C}$ for further 2.5 months until the start of the SOFT system (referred to as "SOFT sediment"). After storage for 3 years at $0^{\circ} \mathrm{C}$, another large sediment core (referred to as "untreated sediment3 years") was processed for bacterial community composition analysis. Although storage at $0^{\circ} \mathrm{C}$, absence of light and the presence of anoxic conditions probably slowed down any kind of heterotrophic microbial activity and geochemical alterations, this core was used to track possible changes in diversity due to storage issues, in particular changes of oil-degrading deltaproteobacterial sulfate reducers.

Sediments were mostly sandy with porosity around 0.4. Measured concentrations of alkanes in untreated sediments were below the detection limit of $<0.1 \mathrm{ng} \mathrm{ml}^{-1}$ (Mishra et al., this issue). Light (i.e., low viscosity/specific gravity), live crude oil (i.e., containing dissolved gas in solution) for the SOFT experiment was provided by Dea Deutsche Erdoel AG and originated from the North Sea, Mittelplate (sampled in February 2013). Seepage was simulated in the SOFT core by pumping petroleum at a constant rate through the core from bottom to top, while artificial oxic seawater diffused into the sediment from the ventilated supernatant. The experiment was stopped after incubation for 190 days at $16^{\circ} \mathrm{C}$ in the dark. Sediment cores ("untreated," SOFT core, and "untreated-3 years") were sliced in one or two centimeter thick slices and immediately frozen at $-20^{\circ} \mathrm{C}$ until use for DNA extraction. Experimental set up of the SOFT core was too complicate for replication, yet we consider adjacent, neighboring layers as technical replicates. More details on sampling procedure, SOFT system setup, as well as pore water sulfate, sediment methane, and sulfate reduction activity measurements are provided in Mishra et al. (this issue).

\section{DNA Extraction}

DNA was extracted from $1 \mathrm{~g}$ sediment per depth layer with the UltraClean soil DNA isolation kit (MO BIO, Carlsbad, CA, USA) according to the manufacturer's protocol for maximum yields. An initial cell lysis step was introduced by adding $0.02 \mathrm{mg}$ $\mathrm{ml}^{-1}$ proteinase K (Merck, Darmstadt, Germany) to the sample and incubating for $50 \mathrm{~min}$ at $37^{\circ} \mathrm{C}$ with moderate shaking. The sediments were then added to the bead solution tubes and the manufacturer's protocol was followed. 


\section{Sequencing of 16S rRNA Genes}

Bacterial 16S rRNA genes were amplified from DNA extracted from (i) untreated sediments, (ii) untreated-3 years sediments, and (iii) SOFT sediments with the primer pair Bakt_341F (5'-CCTACGGGNGGCWGCAG-3')/Bakt_785R (5'-GACTACHVGGGTATCTAATCC- $3^{\prime}$ ) (Herlemann et al., 2011). For each sample, at least six replicate PCR reactions (20 $\mathrm{Ml}$ volume) per primer pair were carried out containing each $0.5 \mu \mathrm{M}$ primer each, $250 \mu \mathrm{M}$ dNTPs, $0.3 \mu \mathrm{g} / \mu \mathrm{l}$ BSA, $1 \times$ PCR buffer, $0.25 \mathrm{U}$ Taq polymerase (5Prime, Germany) or alternatively $1 \mathrm{U}$ Phusion High Fidelity Taq polymerase (New England Biolabs, Ipswich, MA, USA), and 10-25 ng template under the following conditions: initial denaturation at $95^{\circ} \mathrm{C}$ for $5 \mathrm{~min}$, followed by 35 cycles of denaturation $\left(96^{\circ} \mathrm{C}, 1 \mathrm{~min}\right)$, annealing $\left(58^{\circ} \mathrm{C}, 1 \mathrm{~min}\right)$, elongation $\left(72^{\circ} \mathrm{C}, 2 \mathrm{~min}\right)$, and a final elongation step $\left(72^{\circ} \mathrm{C}, 10 \mathrm{~min}\right)$. The replicate PCR reactions were pooled, $500 \mathrm{bp}$-amplicons extracted from an agarose gel $(1.5 \% \mathrm{w} / \mathrm{v})$ and purified using the MinElute PCR Purification Kit (Qiagen) according to the manufacturer's recommendations.

Amplicons retrieved from untreated and SOFT sediments were analyzed by massive parallel tag sequencing on a 454 Life Sciences GS FLX sequencer (Roche, Basel, Switzerland) at the Max Planck-Genome-Centre, Cologne, Germany. The raw reads were submitted to a rigorous quality control procedure using a mothur version 1.32.1 routine (Schloss et al., 2009) including trimming and quality filtering of the reads (quality scores $\geq 35$ in a $50 \mathrm{nt}$ window, no ambiguous bases, and homopolymers $\leq 8 \mathrm{nt}$ ). Chimeras were identified and removed using UCHIME (Edgar et al., 2011). Amplicons retrieved from untreated-3 years sediments were sequenced on a HiSeq 2500 sequencer (2x 250 bp; Illumina, San Diego, CA, USA) at the Max Planck-Genome-Centre, Cologne, Germany. Reads were quality trimmed $($ trimq $=20$, minlength $=238)$ and merged (overlap >12) using software package BBmap v4.3 and split using mothur v1.33.3 (Schloss et al., 2009). Reads were further processed with a modified MiSeq SOP (Kozich et al., 2013, page accessed in May 2016) using mothur including uchime chimera removal (Edgar et al., 2011).

Archaeal 16S rRNA genes were amplified with primers Arch20F (5'-TTC CGG TTG ATC CYG CCR G-3') (Massana et al., 1997)/Arch519R (5'-GGTDTTACCGCGGCKGCTG-3'; Sørensen and Teske, 2006). Primers were barcoded with the Ion Xpress barcodes and extended for ligation with Ion A and Ion truncated P1 adapters at the $5^{\prime}$ end. For each sample PCRs $(50 \mu \mathrm{l}$ volume) were carried out containing $0.5 \mu \mathrm{M}$ primer each, $250 \mu \mathrm{M}$ dNTPs, $0.3 \mu \mathrm{g} / \mu \mathrm{l} \mathrm{BSA}, 1 \times$ PCR buffer, $0.25 \mathrm{U}$ Taq polymerase (5Prime, Germany), about $20 \mathrm{ng}$ template under the following conditions: initial denaturation at $95^{\circ} \mathrm{C}$ for $5 \mathrm{~min}$, followed by 30 cycles of denaturation $\left(94^{\circ} \mathrm{C}, 1 \mathrm{~min}\right)$, annealing $\left(58^{\circ} \mathrm{C}, 1 \mathrm{~min}\right)$, elongation $\left(72^{\circ} \mathrm{C}, 3 \mathrm{~min}\right)$, and a final elongation step $\left(72^{\circ} \mathrm{C}, 10 \mathrm{~min}\right)$. The reactions were separated on an E-Gel SizeSelect Gel (Invitrogen) and the 500 bp-amplicon extracted following the manufacturer's protocol. Then, the PCR product was purified using the MinElute PCR Purification Kit (Qiagen) according to the manufacturer's recommendations. Sequencing of an equimolar pool of different amplicons was carried out on the Ion Torrent Personal Genome Machine
(PGM) system using the Ion PGM ${ }^{\mathrm{TM}}$ Sequencing 400 Kit (both Life Technologies) following the standard protocol (Ion $314^{\mathrm{TM}}$ Chip v2). The raw reads were submitted to a rigorous quality control procedure using BaseCaller V4.2 manufacturer's default parameters including trimming and quality filtering of the reads with minor modifications (trim-qual-cutoff $=15$; trim-qualwindow-size $=20$ ).

According to the revised taxonomic thresholds (Yarza et al., 2014) for a genus, which was updated to $94.5 \%$ sequence identity, the bacterial and archaeal quality reads were clustered using mothur v1.32.1 (Schloss et al., 2009) for subsequent diversity analysis.

All sequence reads were processed for taxonomic assignment by the SILVA NGS analysis pipeline (SILVAngs 1.3, Quast et al., 2013) using SILVA SSU Ref dataset release 119.1 and 123.1.

Raw reads were deposited at the EBI Short Read Archive (SRA) and can be accessed under study accession number SRP070456.

\section{MasD Amplification, Cloning and Sequencing}

The delta subunit of the 1-methyl alkyl succinate synthase gene (mas D) was amplified from SOFT core DNA (layers 0-1 cm, 2$4 \mathrm{~cm}, 4-6 \mathrm{~cm}, 6-8 \mathrm{~cm}$ ) using the primer pair $7757 \mathrm{f}-1, \mathrm{f}-2$ (TCG GAC GCG TGC AAC GMY CTG A; MasD amino acid position 395 in strain $\mathrm{HxN1}$; accession number CAO03074) and $7766 \mathrm{f}$ (TGT AAC GGC ATG ACC ATT GCG CT; position 398 in HxN1)/8543r (TCG TCR TTG CCC CAY TTN GG; position 657 in HxN1; von Netzer et al., 2013). For each sample, eight replicate PCRs (20 $\mu \mathrm{l}$ volume) were carried out containing, $1 \mu \mathrm{M}$ primer each, $250 \mu \mathrm{M}$ dNTPs, $0.3 \mu \mathrm{g} / \mu \mathrm{l}$ BSA, $1 \times$ PCR buffer, $0.25 \mathrm{U}$ Taq polymerase (5Prime, Germany) under the following conditions: initial denaturation at $95^{\circ} \mathrm{C}$ for $5 \mathrm{~min}$, followed by 35 cycles of denaturation $\left(96^{\circ} \mathrm{C}, 1 \mathrm{~min}\right)$, annealing $\left(58^{\circ} \mathrm{C}\right.$, $1 \mathrm{~min})$, elongation $\left(72^{\circ} \mathrm{C}, 2 \mathrm{~min}\right)$, and a final elongation step $\left(72^{\circ} \mathrm{C}, 10 \mathrm{~min}\right)$. All replicate PCR reactions per sample were pooled, precipitated with ethanol, and the 800 bp-amplicons were extracted from an agarose gel $(1.5 \% \mathrm{w} / \mathrm{v})$ and purified using the MiniElute PCR Purification Kit (Qiagen) according to the manufacturer's recommendations. Cloning and Sanger sequencing was performed as described previously in Kleindienst et al. (2012). MasD sequences were clustered at $96 \%$ amino acid identity based on 120 amino acid positions (Pos. 398-500, HxN1) using a distance matrix in mother (Schloss et al., 2009).

Mas D sequences from this study have been deposited in the EMBL, GenBank, and DDBJ nucleotide sequence database under accession numbers LT546441 to LT546456.

\section{Phylogenetic Analysis}

A 16S rRNA-based phylogenetic tree was calculated showing the relationship of described anaerobic hydrocarbon-degrading bacteria to selected reference sequences within the domain Bacteria. The tree was calculated using nearly full-length sequences ( $>1350 \mathrm{bp})$ by neighbor joining analysis in combination with filters which consider only $50 \%$ conserved regions of the $16 \mathrm{~S}$ rRNA. Coverage of CARD-FISH probes used in this study are highlighted in the tree. 
The MasD phylogenetic tree was calculated by maximum likelihood analysis (PhyML algorithm and Blosum 62 substitution model or Phylip ProML and Dayhoff) with a subset of 280 partial deduced amino acid sequences. Filters were applied considering 196 amino acid positions (Pos. 436-637, strain $\mathrm{HxN1}$ ) that were conserved in at least $25 \%$ of the sequences. The affiliation of MasD sequences retrieved from SOFT core layers is shown together with selected reference sequences from cultured alkane degraders, enrichment cultures, clone libraries or metagenomes. Only one representative sequence per MasD-OTU 0.96 is shown in the tree. Unstable branching orders are shown as multifurcations. Sequences from benzylsuccinate synthases (BssA) and naphthyl-methylsuccinate synthases (NmsA) were used as outgroup.

\section{Diversity Analysis}

Using the 16S rRNA gene sequence datasets from untreated and SOFT sediments, the sequence abundance tables after subsampling were used to calculate Inverse Simpson diversity indices and Chaol richness using mothur v1.32.1 (Schloss et al., 2009). Dissimilarities (Chao, 1984; Hill et al., 2003) were calculated using the Bray-Curtis dissimilarity coefficient (Bray and Curtis, 1957). The resulting beta-diversity matrices were used for three-dimensional non-metric multidimensional scaling (NMDS) ordinations (Kruskal, 1964). Stress values below 0.2 indicate that the multidimensional dataset is well represented by the $3 \mathrm{D}$ ordination. To test whether the inclusion of singletons affected further statistical tests we generated NMDS ordinations with and without rare biosphere (OTU comprising $<0.01 \%$ of total sequences) and compared them using Procrustes correlation analysis (Gower, 1975). Procrustes correlation was highly significant (coefficient $=0.935$ ). Furthermore, to test the effect of subsampling we generated NMDS ordinations using all obtained OTUs and OTUs after subsampling. Procrustes correlation was 0.911. Neither subsampling nor the presence of rare biosphere OTUs did affect the overall trend. Thus we decided to include all data in our analyses, if not stated otherwise, to be able to identify types of microorganisms which can switch from rare to dominant modes of distribution. Taxa that were shared between untreated and SOFT sediments or between layers were calculated using the Jaccard dissimilarity coefficient (i.e., presences/absence). Constrained correspondence analysis (CCA) was carried out to evaluate the combined effects of sulfate, methane, and sulfate reduction rates on the microbial community composition. The significance of these effects was assessed by analysis of similarity (ANOSIM). Environmental factors were fitted in $\mathrm{R}$ with the function envfit (vegan package) onto the ordination. The projections of points onto vectors have maximum correlation with corresponding environmental variables, and the factors show the averages of factor levels.

Sequences from untreated-3 years sediments were not included into the diversity analysis because OTU clustering might be biased due to the use of different sequencing platforms.

\section{Catalyzed Reporter Deposition Fluorescence In Situ Hybridization (CARD-FISH)}

Sediment samples from the untreated core, untreated-3 years core and SOFT core have been fixed in 3\% formaldehyde for $3 \mathrm{~h}$ at $4^{\circ} \mathrm{C}$, washed with $1 \mathrm{x}$ PBS and stored in ethanol-PBS $(1: 1)$ at $-20^{\circ} \mathrm{C}$. Samples were diluted, four times ultrasonicated on ice at $20 \%$ intensity, 20 cycles, 30 s (Bandelin Sonopuls HD200), and filtered on a $0.22 \mu \mathrm{m}$ pore size polycarbonate filter. In situ hybridizations with horseradish peroxidase (HRP)labeled probes followed by fluorescently labeled tyramide signal amplification (catalyzed reporter deposition) were carried out as described previously (Pernthaler et al., 2002). Permeabilization was performed by lysozyme treatment $\left(10 \mathrm{mg} \mathrm{ml}^{-1}\right)$ for $60 \mathrm{~min}$ at $37^{\circ} \mathrm{C}$. Hybridization was done at $46^{\circ} \mathrm{C}$. Hybridized samples were analyzed with an epifluorescence microscope (Nikon Eclipse $50 i)$. For each probe and sample, $>1000$ DAPI stained cells and their corresponding FISH signals were counted. Used probes (ordered from biomers.net; Ulm, Germany) and formamide concentrations are given in Supplementary Table S1.

\section{RESULTS AND DISCUSSION}

\section{Microbial Diversity in Untreated and SOFT Sediments}

We obtained 146,181 bacterial and 393,789 archaeal raw $16 \mathrm{~S}$ rRNA gene sequences from untreated and SOFT sediments. For bacterial diversity, all depth intervals $(0-16 \mathrm{~cm}$ depth) were analyzed, while for archaeal diversity the analysis was restricted to the methanogenic zone $(6-16 \mathrm{~cm}$ depth) to study archaea potentially involved in methanogenic hydrocarbon degradation. Sequencing of bacterial and archaeal 16S rRNA genes were performed by Roche 454 and Ion Torrent technology, respectively. Potential different biases caused by the use of different sequencing platforms are not of relevance here as we handle both datasets separately and do not interpret differences between the bacterial and archaeal diversity. After strict quality trimming about $40 \%$ of the raw reads were left for analysis (Table 1), with length $>430 \mathrm{bp}$ for Bacteria and $>310$ bp for Archaea. According to the recently revised taxonomic thresholds (Yarza et al., 2014), a total of 2478 bacterial and 153 archaeal genus-level operational taxonomic units $(94.5 \%$ sequence identity; $\mathrm{OTU}_{0.945}$ ) were detected in the untreated sediment and 2558 bacterial and 241 archaeal OTU 0.945 in SOFT sediment. The bacterial dataset contained $4 \%$ absolute single sequence OTU $\left(\mathrm{SSO}_{\mathrm{abs}}\right.$; OTU $\mathrm{OT}_{0.945}$ that occurred only once in the whole dataset) and $11 \%$ relative single sequence OTU ( $\mathrm{SSO}_{\text {rel }}$; $\mathrm{OTU}_{0.945}$ that occurred only once in at least one sample but are more frequent in other samples) and the archaeal dataset contained $7 \% \mathrm{SSO}_{\mathrm{abs}}$ and $19 \% \mathrm{SSO}_{\text {rel }}$. Chao 1 bacterial genuslevel richness estimates based on standardized datasets were similar for untreated and SOFT sediments and ranged between 396 and 532 OTU $_{0.945}$ (Table 1). Archaeal richness estimates were one order of magnitude lower and ranged between 30 and $35 \mathrm{OTU}_{0.945}$ in untreated sediments and between 57 and 81 


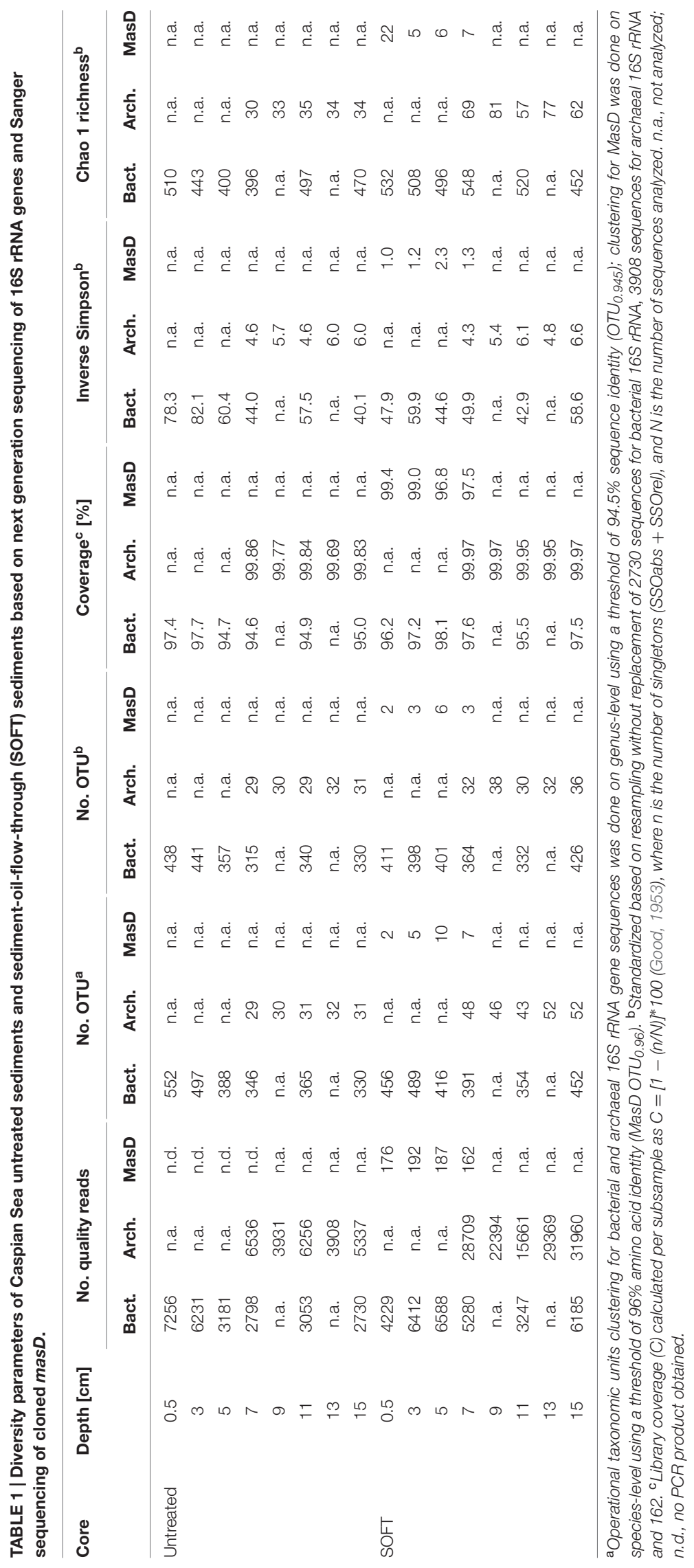


$\mathrm{OTU}_{0.945}$ in SOFT sediments. Coverage was $>94.6 \%$ (Bacteria) and $>99.6 \%$ (Archaea) for all layers studied and rarefaction curves nearly reaching saturation for most samples indicated sufficient sequencing effort (Supplementary Figure S2). The observed bacterial richness on genus-level is rather low compared to values for species-level diversity reported in other studies investigating benthic habitats, which ranged between ca. $300 \mathrm{OTU}_{0.97}$ at hydrothermal vents to ca. 6500 bacterial OTU 0.97 at the deepsea surface and ca. 1500 archaeal OTU 0.97 in coastal sediments (Ruff et al., 2015). In untreated sediments inverse Simpson for Bacteria ranged between 40.1 and 82.1 and was highest in the two uppermost layers. In SOFT sediments inverse Simpson ranged between 42.9 and 59.9. With an inverse Simpson index between 4.3 and 6.6, archaeal diversity was low in untreated and SOFT sediments (Table 1).

\section{Microbial Community Structure in Untreated and SOFT Sediments}

The uppermost layer of the SOFT core $(0-1 \mathrm{~cm}$ depth) was excluded from similarity analysis due to the influence of an accumulated oil slick above and oxygen penetration into this layer.

Pairwise comparison of untreated and SOFT sediments resulted in $43 \%$ shared bacterial OTU $\mathrm{OT}_{0.945}$ but only $23 \%$ shared archaeal OTU 0.945 (Supplementary Table S2). Communities were as similar to each other within the core as between identical layers of the two cores: On average, 55\% bacterial and 59\% archaeal $\mathrm{OTU}_{0.945}$ were shared within a core versus $51-56 \%$ bacterial and $59 \%$ archaeal OTU 0.945 shared between identical layers (Supplementary Table S3).

Similarity of bacterial (Figures 2A,B; 11 samples) and archaeal (Figures 2C,D; 10 samples) communities was visualized by NMDS. Bacterial dissimilarity (Bray-Curtis) of samples is supported by an $R$ value of 0.49 ( $p<0.001)$. Archaeal dissimilarity (Bray-Curtis) of samples is supported by an $R$ value of $0.57(p<0.001)$. The bacterial and archaeal community differed significantly between different sediment layers as confirmed by ANOSIM (Figures 2A,C; Bacteria: $R=0.46-0.73$, $p<0.001$; Archaea: $R=0.75 ; p<0.001)$. Between the cores, community was only significantly different for Archaea $(R=0.73$; $p<0.001)$ but not for Bacteria $(R=0.31, p=0.05$; Figures $2 \mathbf{B}, \mathbf{D})$.

Fitting of environmental variables showed significant correlations for methane $(p=0.003)$, suggesting that methane likely influenced the observed pattern of archaeal taxonomic clustering, while sulfate reduction rates $(p<0.001)$ and sulfate concentration $(p=0.07$ ) likely influenced bacterial taxonomic clustering. As mentioned earlier, replication of the SOFT experiment was not feasible; however, we consider adjacent layers of each core as technical replication, providing a certain confidence level for the comparison between the untreated and the SOFT sediments.

\section{Bacterial Taxa in Untreated and SOFT Sediments}

On phylum-level, the composition of the bacterial community was similar in untreated and SOFT sediments (Supplementary
Figures S3A,B). Proteobacteria dominated throughout the cores accounting for 56 and $50 \%$ of bacterial $16 \mathrm{~S}$ rRNA gene sequences in untreated and SOFT sediments, respectively. Planctomycetes, Actinobacteria, and Chloroflexi (5-7\% each) were the next sequence-abundant phyla. Within Proteobacteria, one-third (untreated sediment) and one-half (SOFT) of the sequences were assigned to the class Deltaproteobacteria (Figures 3A,B) while almost one-half (untreated sediment) and one-third (SOFT) were assigned to Gammaproteobacteria. In comparison, previous studies investigating the microbial community in natural Caspian Sea sediments reported similar taxa with Proteobacteria being most abundant (33\% of reads on average), followed by Planctomycetes (14\%) and Chloroflexi (12\%, Mahmoudi et al., 2015).

The major part of gammaproteobacterial sequences in SOFT and untreated sediment affiliated with Woeseiaceae/JTB255 (29 and 30\%), recently described as ubiquitous chemolithoautotrophic key players potentially involved in sulfur oxidation in marine sediments (Dyksma et al., 2016). Alphaproteobacterial genera described to aerobically degrade aromatic hydrocarbons (Kim and Kwon, 2010), e.g., Novosphingobium, Sphingomonas, Thalassospira, and Kordiimonas, have been found in the SOFT dataset retrieved from $0.5 \mathrm{~cm}$ depth. As the top layer in the SOFT core was oxic and was covered by an oil slick, the detection of sequences from known hydrocarbon degraders suggested the development of an aerobic hydrocarbon-degrading bacterial community. Furthermore, sequences related to known aerobic gammaproteobacterial hydrocarbon degraders (Kleindienst et al., 2016) have also been detected in this layer including Cycloclasticus, Marinobacter, Alcanivorax, and Thalassolituus. In particular, the relative abundance of sequences assigned to Cycloclasticus increased remarkably by a factor of 10 from $0.1 \%$ in untreated sediments to $1.0 \%$ in the oxic SOFT layer. Cycloclasticus spp. have been repeatedly isolated from marine sediments and were shown to use aromatic hydrocarbons such as naphthalene, phenanthrene, anthracene, fluorenes, and toluene as sole carbon source (Dyksterhouse et al., 1995; Geiselbrecht et al., 1998; Chung and King, 2001; Cui et al., 2014). Likewise, culture-independent studies supported that Cycloclasticus spp. likely play a major role in the degradation of petroleum polycyclic aromatic hydrocarbons in coastal (Coulon et al., 2012), deep-sea (Cui et al., 2008; Dong et al., 2015; Gutierrez et al., 2015), and estuarine (McKew et al., 2007; Niepceron et al., 2010) sediments.

Methanogenesis and sulfate reduction were identified as important processes in the anaerobic degradation of hydrocarbons during petroleum seepage in Caspian Sea sediments (Mishra et al., this issue). Therefore, Deltaproteobacteria were analyzed in greater detail because most known anaerobic hydrocarbon degraders belong to this class (Figure 1). A slight increase of relative sequence abundance of Deltaproteobacteria was observed in the anoxic layers of the SOFT core between 2 and $8 \mathrm{~cm}$ depth $(17-25 \%$ in untreated sediments versus $23-35 \%$ in SOFT sediment Figures 3D,E). Of these, more than one-half could be further assigned to the order Desulfobacterales with highest frequency between 4 and $12 \mathrm{~cm}$ depth (Figure 3E and Supplementary Table S4). 

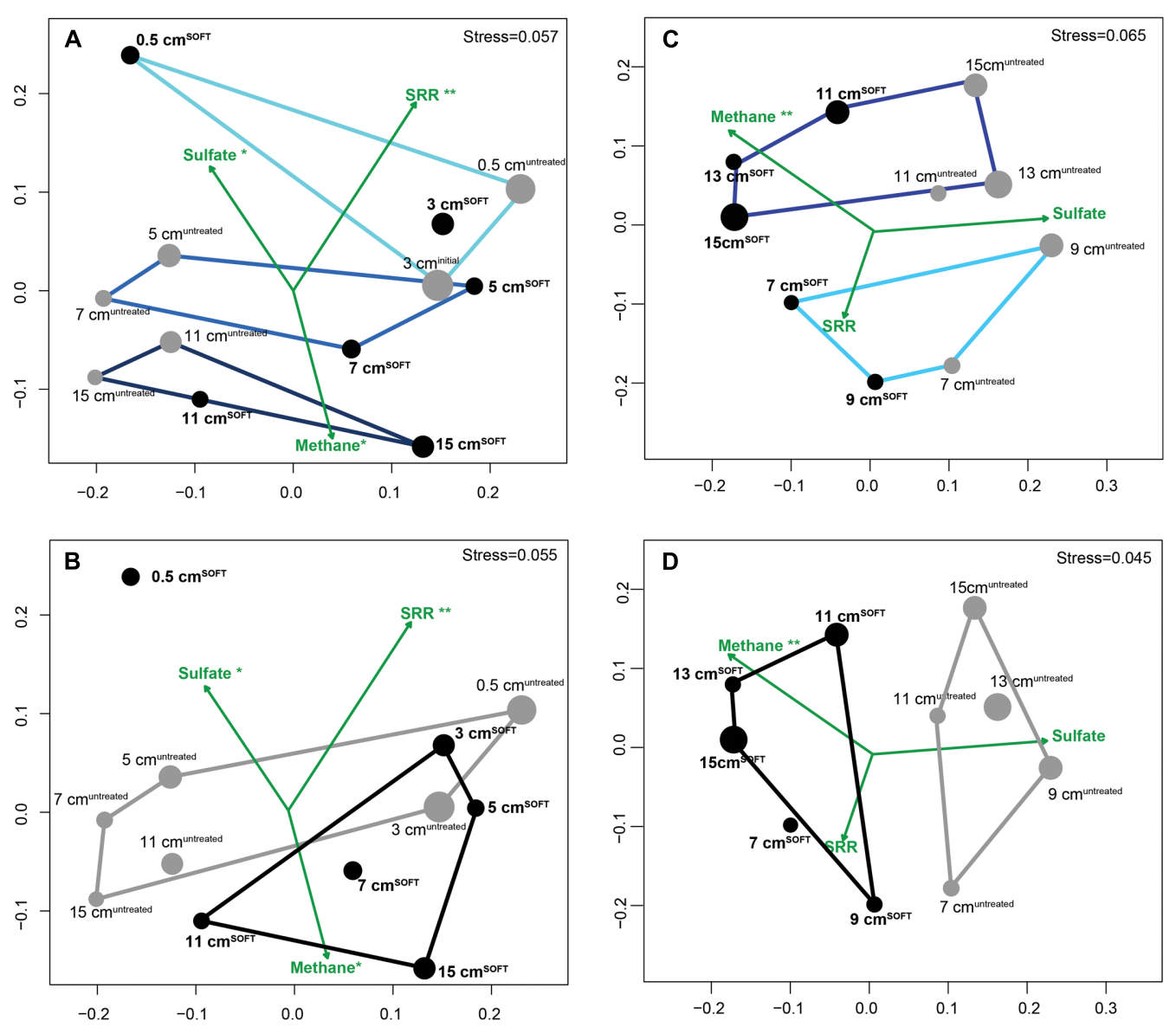

FIGURE 2 | Similarity of bacterial (A,B) and archaeal (C,D) communities visualized by non-metric multidimensional scaling (NMDS) of Bray-Curtis dissimilarity matrices based on OTU 0.945 relative abundance data with environmental variables fitted as vectors. Gray dots represent untreated sediment subsamples and black dots represent SOFT sediment subsamples. The size of the dots reflects the evenness of the subsamples (inverse Simpson index). Defined subgroups are depicted as polygons. Dataset for SOFT core layer $0.5 \mathrm{~cm}$ depth was excluded from the analysis because this layer became oxic and was influenced by an oil slick forming on top of the core during the experiment. Significance levels are indicated next to the tested parameters methane, sulfate, and sulfate reduction rates $(* * p<0.01$;

$\left.{ }^{*} p<0.1\right)$. SRR, sulfate reduction rates.

Within Desulfobacterales, the uncultured Sva0081-group, which was first described in clone libraries from Svalbard sediments (Ravenschlag et al., 1999) and includes sulfate-reducing endosymbionts of the gutless marine oligochaete Olavius sp., was the most sequence-abundant group with $2.3-5.7 \%$ of total sequences (Supplementary Table S4). Relative abundance did not differ remarkably between untreated and SOFT sediments supporting current knowledge, that Sva0081 bacteria are ubiquitous and highly abundant members of SRB communities in diverse benthic habitats (Mußmann et al., 2015). A second sequence-abundant group was the uncultivated clade SEEP1d with up to $3.4 \%$ of total bacterial sequences between 10 and $16 \mathrm{~cm}$ in both, untreated and SOFT sediments. SEEP1d was repeatedly found at marine seep sites but no function has yet been assigned (Knittel et al., 2003; Schreiber et al., 2010).

Many known groups of hydrocarbon-degrading SRB (Figure 1) were found in our dataset, some of which showed an increase of relative sequence abundance after oil-flow-through in the zone of highest sulfate reduction at $2-8 \mathrm{~cm}$ SOFT depth; other did not (Supplementary Table S4). Most sequenceabundant and at the same time strongly increased were relatives of Desulfobacula with up to $8.1 \%$ of total bacterial sequences compared to $1.7 \%$ in untreated sediments. Desulfobacularelated sequences retrieved from SOFT sediments showed 96\% sequence similarity with $D$. toluolica and D. phenolica. Desulfobacula spp. can use short-chain fatty acids and simple organic compounds as electron donors but also various aromatic compounds such as toluene or phenol (Bak and Widdel, 1986; Rabus et al., 1993; Kuever et al., 2001). Putative long-chain alkane-degrading SRB of clade LCA2 (Kleindienst et al., 2014, Figure 1) were less sequence-abundant but increased in SOFT sediments, with $0.2 \%$ vs. $1.9 \%$, as well as clade Cyhx (Jaekel et al., 2015, $0.2 \%$ vs. $0.6 \%$ ), suggested $\mathrm{C}_{2}-\mathrm{C}_{4}$ alkane degraders (Adams et al., 2013, 0.1\% vs. 1.1\%), Desulfosarcina spp. ( $0.6 \%$ vs. $1.5 \%)$, and s2551group ( $0.5 \%$ vs. $1.1 \%)$, reported as oil-degrading bacteria in an oil-reservoir model column (Myhr et al., 2002). Relative sequences abundances of putative short-chain alkane-degrading clade SCA1, which comprises 


\section{PROTEOBACTERIA}

\section{A}

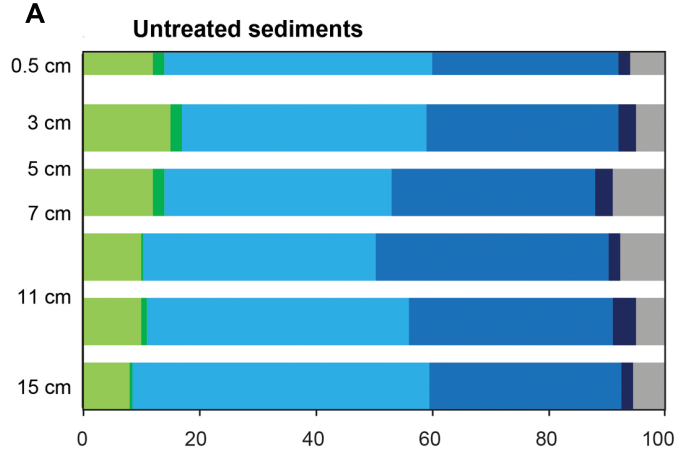

B
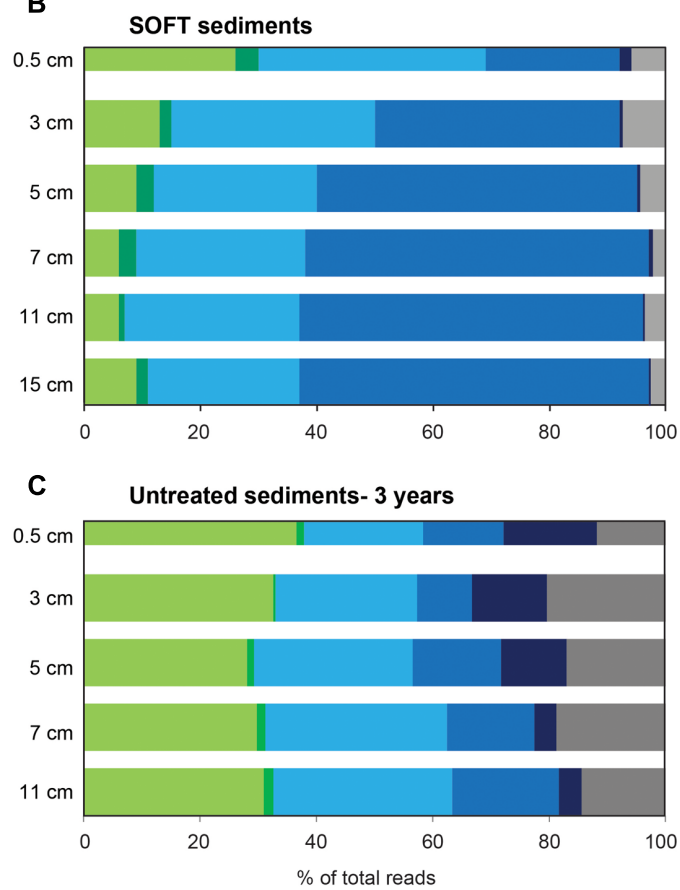

Taxa (class level)

- Alphaproteobacteria Deltaproteobacteria

- Betaproteobacteria $\square$ Epsilonproteobacteria

Gammaproteobacteria unclassified Proteobacteria

\section{DELTAPROTEOBACTERIA}
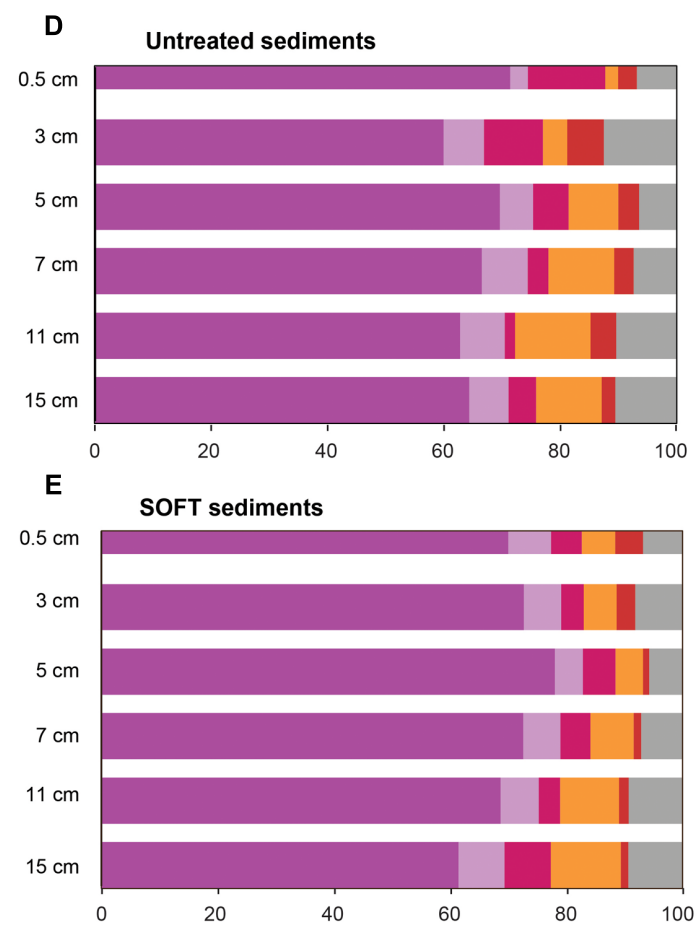

F Untreated sediments- 3 years

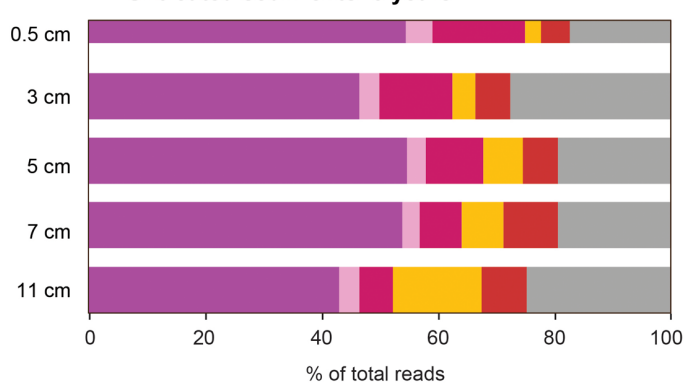

Taxa (order level)

- Desulfobacterales Syntrophobacterales

Desulfarculales Myxococcales

- Desulfuromonadales other Deltaproteobacteria

FIGURE 3 | Community composition of (A-C) Proteobacteria and (D-F) Deltaproteobacteria in untreated (A,D), untreated-3 years (C,F) and SOFT (B,E) sediments from Caspian Sea based on 16S rRNA gene sequencing. Petroleum flow-through resulted in a community shift in SOFT sediments toward a higher percentage of deltaproteobacterial sequences. Storage of untreated sediments for 3 years at $0^{\circ} \mathrm{C}$ in the dark $(\mathbf{C}, \mathbf{F})$ resulted in a shift toward $A / p h a p r o t e o b a c t e r i a$ and Epsilonproteobacteria and a decrease of Deltaproteobacteria indicating that long-term storage did not favor the growth of deltaproteobacterial,

hydrocarbon-degrading sulfate reducers identified in this study.

the only isolated $n$-butane-degrading strain BuS5 (Kniemeyer et al., 2007), did not increase after oil-flow-through and were constantly low with $0.3-0.8 \%$ of total bacterial sequences in both, untreated and SOFT sediments. No remarkable change $(0.2 \%$ vs. $0.3 \%)$ has also been observed for sequences affiliated with Desulfococcus oleovorans Hxd3 (Aeckersberg et al., 1991), clade LCA1 (0.1\%), Desulfatiglans-group (1.1-2.1\%), and clade SB-29 (around 0.5\%). Sequences related to known hydrocarbondegraders within the Firmicutes, i.e., Propane60GuB (Kniemeyer et al., 2007) and Desulfotomaculum sp. strain Ox39 (Morasch et al., 2004), were not retrieved. However, relative abundance of sequences within Peptococcaceae, in particular those related to autotrophic hydrogen-utilizing SRB of the genus Desulfosporosinus spp., increased at $15 \mathrm{~cm}$ depth in SOFT sediments (untreated sediments: 1.1\%; SOFT: $4.8 \%$ of total bacterial sequences).

Due to logistical complications, the SOFT core was stored for three more months after sampling and processing the 
untreated sediments. To verify that observed changes in the SRB community in SOFT sediments were independent of storage effects but caused by oil-flow-through, a parallel core stored for 3 years at $0^{\circ} \mathrm{C}$ in the dark ("untreated-3 years") was analyzed by Illumina tag sequencing. After strict quality trimming, 42982 bacterial 16S rRNA gene sequences were taxonomically assigned using the SILVAngs pipeline. The composition of the microbial communities was compared on class level to avoid potential bias due to the use of different sequencing platforms. Furthermore, we restricted the comparison to Proteobacteria because most sulfate reducers detected in SOFT sediments belonged to this phylum. Storage of untreated sediments for 3 years at $0^{\circ} \mathrm{C}$ in the dark resulted in a shift toward Alphaproteobacteria (8-15\% of total bacterial sequences in untreated vs. 26$36 \%$ in untreated-3 years sediments; mainly Rhodobacterales and Rhodospirillales) and Epsilonproteobacteria (2-4\% vs. 416\%; mainly Sulfurovum and Sulfurimonas) and a decrease of Deltaproteobacteria (32-40\% vs. 9-18\%; Figures 3C,F). We therefore conclude that the observed increase of relative sequence abundance of hydrocarbon-degrading deltaproteobacterial SRB in SOFT sediments points to a positive effect of petroleum on the growth of this bacterial group in the oil-flow-through system rather than being caused by storage effects.

\section{Archaeal Taxa in Untreated and SOFT Sediments}

On phylum-level, significant differences were observed between the archaeal community in SOFT and untreated sediments (Supplementary Figures S3C,D). In untreated sediments at 7 and $9 \mathrm{~cm}$ depth, most sequence-abundant phylum was Thaumarchaeota (on average $30 \%$ of total archaeal sequences at $7-15 \mathrm{~cm}$ depth with a maximum of $64 \%$ at $7 \mathrm{~cm}$ ), of which all currently known species are chemolithoautotrophic ammoniumoxidizers (Könneke et al., 2014). Below, at 11-15 cm depth, sequences related to euryarchaeotal Marine Benthic Group D and Deep-sea Hydrothermal Vent Euryarchaeotic Group (DHVEG1; $20 \%$ of total archaeal sequences) and Thermoplasmata CCA47 (13\%), a group of uncultivated euryarchaeotal sequences isolated from an anoxic sediment of a sub-saline shallow lake (Laguna de Carrizo, Central Spain, Ferrer et al., 2011), were most abundant. In the SOFT core, Thaumarchaeota had only low sequence frequencies (0.6-2.5\%). Dominant groups were DHVEG, Thermoplasmata ASC21 (9\%) a group of uncultivated Thermoplasmatales isolated from a hot spring in the Lower Culex region of the Lower Geyser Basin, Yellowstone National Park (Saw et al., 2015), and Aenigmarchaeota of the Deep Sea Euryarchaeotic Group (DSEG; 7\% in 14-16 cm). High relative sequence numbers of Methanosarcinales were detected at $7 \mathrm{~cm}$ (7\% of total archaeal sequences) and at $9 \mathrm{~cm}$ (38\%) depth in the SOFT core, whereas in other layers and in untreated sediments they were nearly absent. More than $99 \%$ of the Methanosarcinales sequences affiliated with the genus Methanosarcina. The closest relatives were $M$. semesiae and $M$. lacustris, with a $16 \mathrm{~S}$ rRNA gene similarity of $>98 \%$. Furthermore, only very few sequences ( $<<1 \%$ of total archaeal sequences) affiliated with other known methanogens such as Methanolobus and Methanococcoides (Methanosarcinaceae), Methanosaetaceae, Methanomicrobiaceae, Methanocellaceae, or Methermicoccaceae were detected in SOFT sediments (Supplementary Table S5). Methanotrophs of the ANME clades (ANME-1, ANME-2, ANME-3) and "Candidatus Syntrophoarchaeum," capable of anaerobic butane oxidation (Laso-Pérez et al., 2016) were only sporadically detected. In comparison, previous studies of the microbial community in Caspian Sea sediments identified Thaumarchaeota and Parvarchaeota as dominant in surface layers while Marine Benthic Group B (Lokiarchaeota) dominated the deeper layers (Mahmoudi et al., 2015).

\section{Response of Hydrocarbon-Degrading SRB to Simulated Petroleum Seepage}

Based on identified changes in relative sequence abundance, we selected several groups of SRB as target for quantification by CARD-FISH (Figure 4).

Deltaproteobacteria were most abundant between 0 and $4 \mathrm{~cm}$ depth (Figure 4A). In these layers, deltaproteobacterial cell numbers increased by a factor of 4 compared with numbers in untreated sediment layers and accounted for up to $3.2 \times 10^{8}$ cells $\mathrm{ml}^{-1}$ SOFT sediment (24-28\% of total cells) and up to $8.6 \times 10^{7}$ cells $\mathrm{ml}^{-1}$ untreated sediment (9-17\%). The peak of Deltaproteobacteria in SOFT sediment coincided with the strong decrease of sulfate concentration, highest sulfate reduction rates and the decrease of aliphatic hydrocarbon concentrations (see Mishra et al., this issue) indicating a response of specific hydrocarbon-degrading Deltaproteobacteria. Major decrease of gaseous alkanes was observed above $7 \mathrm{~cm}$ depth (Mishra et al., this issue). Mid- and long-chain alkanes $\left(\mathrm{C}_{12}-\mathrm{C}_{30}\right)$ decreased by about $50 \%$ above $14 \mathrm{~cm}$ depth, further $25 \%$ above $7 \mathrm{~cm}$ and remained relatively constant until top of the core.

Using probe DSB985, we targeted Desulfobacula, Desulfotignum, and Desulfobacterium, genera comprising aromatic hydrocarbon degraders. Members of this target group were detected in high numbers in the SOFT core accounting for up to $6.4 \times 10^{7}$ cells $\mathrm{ml}^{-1}$ sediment ( $7 \%$ of total cells, Figure $4 \mathbf{B}$ ). Cell numbers peaked at $3 \mathrm{~cm}$ depth and strongly decreased below. In untreated sediments, Desulfobacula cell numbers were almost an order of magnitude lower accounting for only $1 \%$ of total cells. Similar low cell numbers were observed in untreated sediments stored for 3 years. Although degradation of aromatic compounds had not been followed during the experiment, we assume a standard composition of the light oil used for flowthrough of about $30 \%$ aromatics, $0-10 \%$ asphaltenes, and major part being alkanes. Highest cell numbers of Desulfobacula-related species were found within the zone of sulfate reduction thus suggesting that this group might be the main consumer of the aromatics in the petroleum.

The yet uncultivated LCA2-group was targeted by probe LCA2-63. Like Desulfobacula, LCA2 cell numbers were highest at $3 \mathrm{~cm}$ depth in SOFT sediments with $5.5 \times 10^{7}$ cells $\mathrm{ml}^{-1}$ sediment ( $6 \%$ of total cells). In both untreated sediments, LCA2 cell numbers were one order of magnitude lower (Figure 4C) and accounted for only $1 \%$ of total cells. SRB of LCA2 had been identified by stable isotope-probing as key players for 

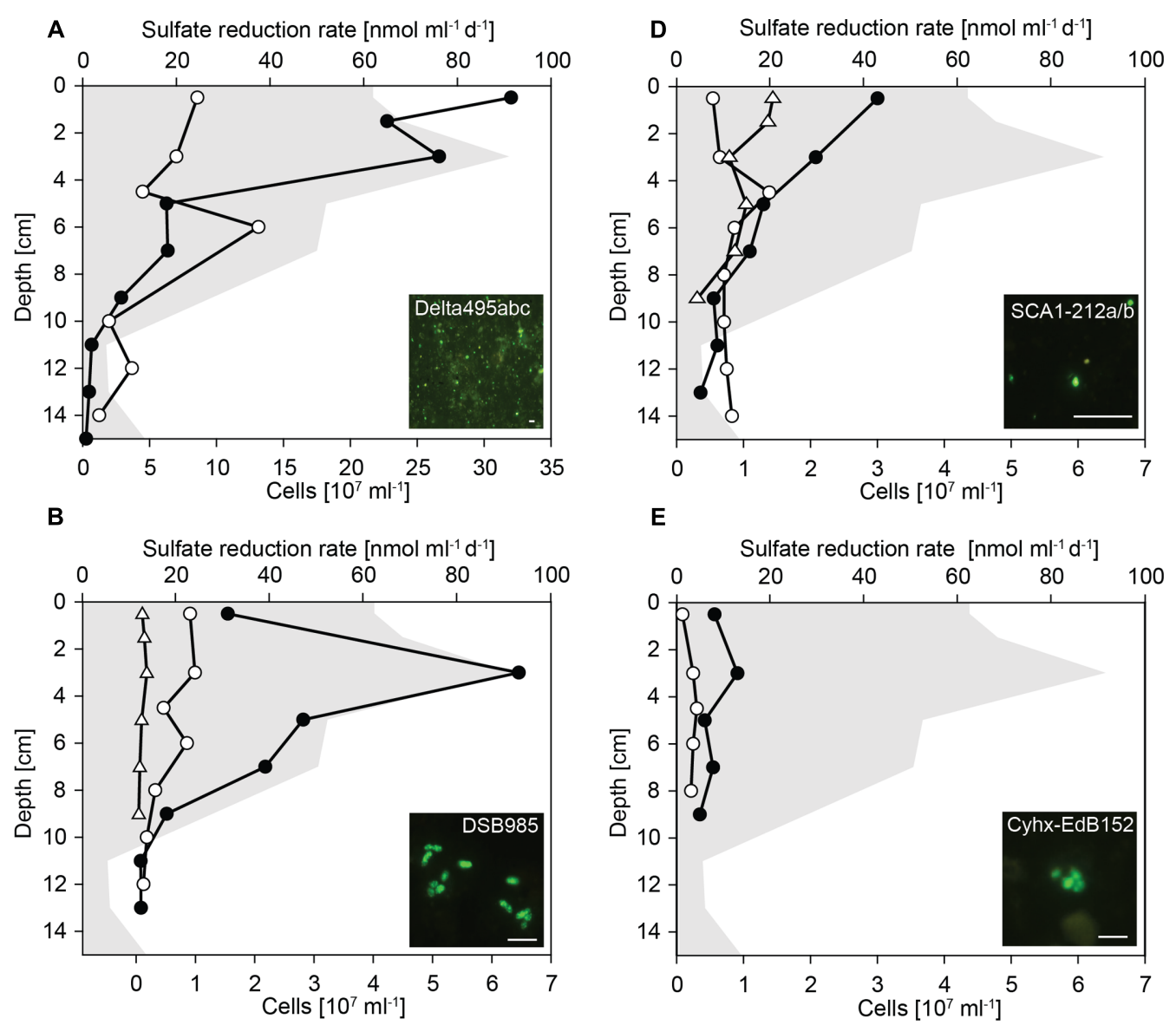

E
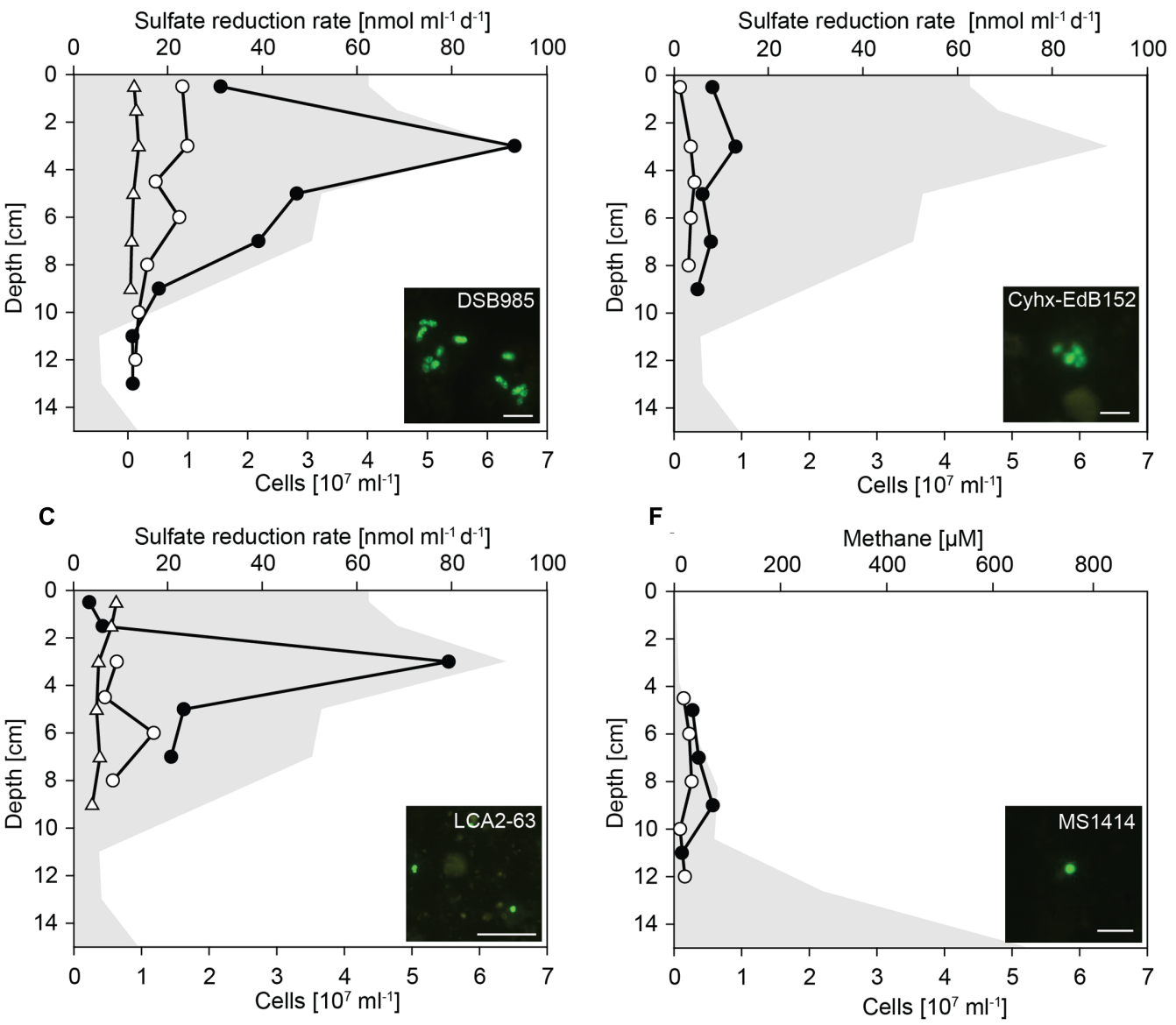

FIGURE 4 | Cell numbers of Deltaproteobacteria and hydrocarbon-degrading SRB in untreated and SOFT sediments. Vertical profiles show specific cell numbers in untreated (white dots) and SOFT (black circles) core sediments as detected by CARD-FISH with (A) probe Delta495abc for Deltaproteobacteria, (B) probe DSB985 for Desulfobacula spp., Desulfotignum spp., and Desulfobacter spp., (C) probe LCA2-63 for clade LCA2, (D) probe SCA1-212a/b for clade SCA1, (E) probes Cyhx-EdB_152/152b for clade Cyhx, and (F) probe MS1414 for Methanosarcina spp., Methanococcoides spp., Methanolobus spp., and Methanohalophilus spp. As reference, cell numbers detected with probes SCA1-212a/b, DSB985, and LCA2-63 were determined in the untreated-3 years core that was stored for 3 years at $0^{\circ} \mathrm{C}$ in the dark (white triangles). Sulfate reduction rates (A-E) and methane concentration (F) in SOFT core sediments are visualized by gray area (data taken from Mishra et al., this issue). Bar $=5 \mu \mathrm{m}$.

long-chain alkane degradation at marine seeps (Kleindienst et al., 2014). The incubation was done with $n$-dodecane as a representative substrate for long-chain alkanes. Here, SRB of LCA2 are suggested as putative main consumers of longchain alkanes in the $2-6 \mathrm{~cm}$ depth layers in SOFT sediment. Accordingly, concentrations of $\mathrm{C}_{12}-\mathrm{C}_{26}$ alkanes dropped to 


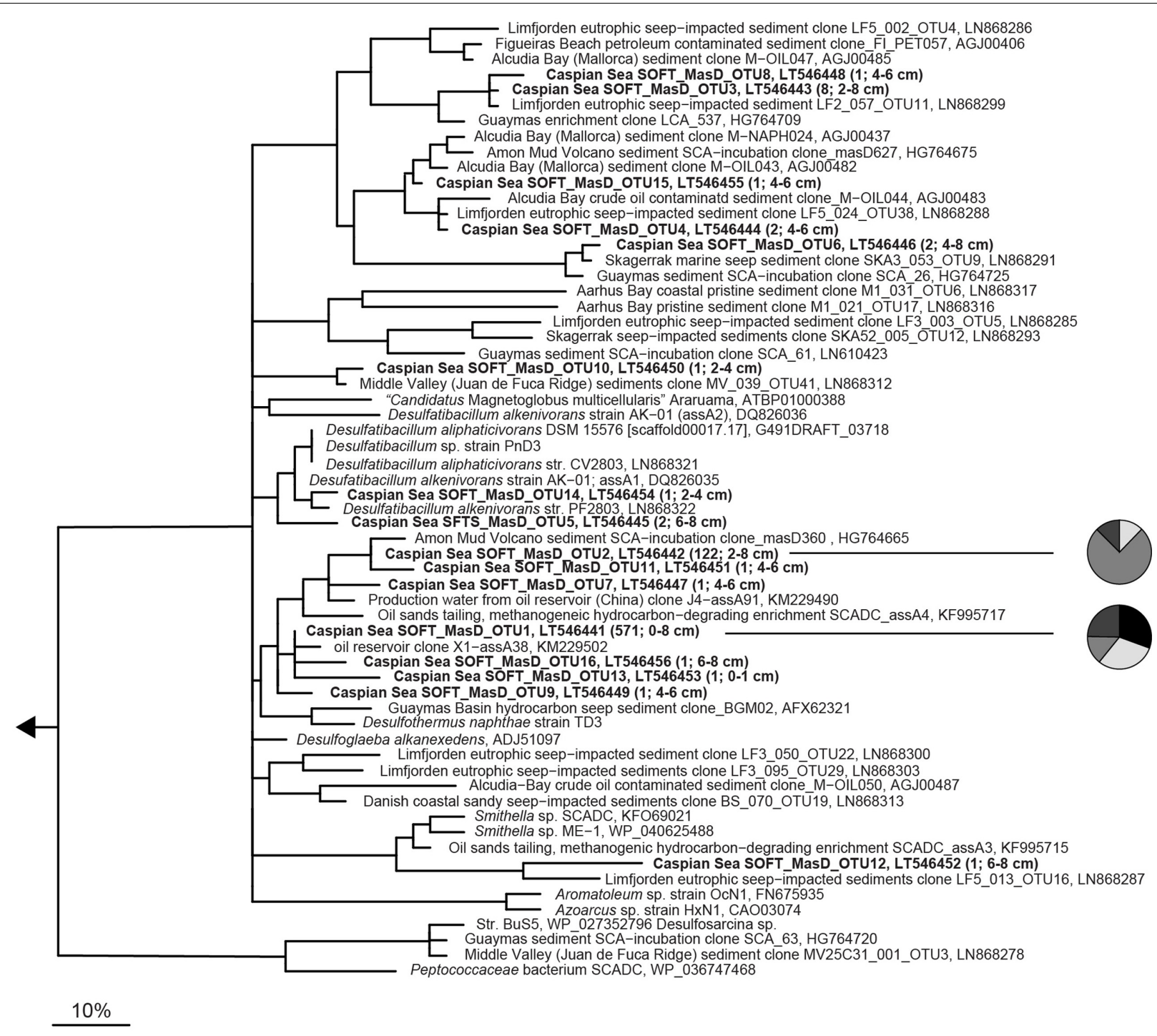

FIGURE 5 | Phylogeny of partial MasD/AssA sequences retrieved from SOFT core sediments and selected reference sequences. Operational taxonomic units (OTU) were defined at a cut-off of 96\% amino acid identity (according to Stagars et al., 2016). Representative sequences for OTUs from SOFT sediments are printed in bold. OTU abundance (number of sequences) and sediment depth are indicated in parenthesis. The scale bar gives $10 \%$ estimated amino acid sequence divergence. Pie charts shown next to the two most abundant OTUs give the distribution in different depth layers. Black, 0-1 cm; white, 2-4 cm; medium gray, 4-6 cm, and dark gray, 6-8 cm depth.

about $20-25 \%$ in these depth layers (Mishra et al., this issue).

Short-chain alkane-degrading clade SCA1 was targeted by probes SCA1-212a and SCA1-212b. SCA1 cell numbers were comparably low for untreated, untreated-3 years and SOFT sediment layers. Only in SOFT sediment at $0-3 \mathrm{~cm}$ depth, SCA1 cell numbers were 3 - to 5-fold higher than in both control sediments $\left(2-3 \times 10^{7}\right.$ cells $\mathrm{ml}^{-1} ; 2 \%$ of total cells; Figure 4D). Isolated or enriched members of SCA, for example strain BuS5, Butane12_GMe, propane12_GMe, and Butane12_HR, use propane or butane as carbon source (Kniemeyer et al., 2007; Jaekel, 2011; Jaekel et al., 2013). We suggest that SCA1 together with others (for example, the $\mathrm{C}_{2}-\mathrm{C}_{4}$ alkane-degrading group,
Adams et al., 2013) are the main consumers of available propane and butane in the SOFT sediment.

Clade Cyhx was targeted by a mix of probe Cyhx28_EdB_152 (Jaekel et al., 2015) and probe Cyhx28_EdB_152b that has been designed in this study. In the zone of sulfate reduction in the SOFT core, representatives of this clade were detected by CARD-FISH in numbers of up to $0.9 \times 10^{7}$ cells $\mathrm{ml}^{-1}$ sediment ( $1 \%$ of total cells, Figure $\left.4 \mathrm{E}\right)$. In all layers of untreated sediments, members of clade Cyhx were close to detection limit of $\leq 0.5 \%$ of total cells. Cyhx-SRB were shown to grow on cyclohexane, but also to use other cyclic alkanes as well as $n$-pentane and $n$-hexane (Jaekel et al., 2015). 


\section{Methanogenic Hydrocarbon Degradation as Response to Simulated Oil Seepage}

Methanogenesis was identified as important process in the anaerobic degradation of hydrocarbons during simulated oil seepage in SOFT sediments. The $\delta^{13} \mathrm{C}$ signal of produced methane showed a decrease from $-33.7 \%$ to $-49.5 \%$ after 190 days of oil seepage indicating microbial methane formation (Mishra et al., this issue). Furthermore, the high methane concentrations in the deep SOFT core layers coincided with a decrease in higher hydrocarbons also supporting methanogenic hydrocarbon degradation. The mechanism driving alkane (mainly hexane) or aromatic hydrocarbon degradation under methanogenic condition is not elucidated yet. It supposedly requires the interaction of syntrophic bacteria, such as members of the family Syntrophaceae (Syntrophus spp., Smithella spp.) or of the order Clostridiales (Desulfotomaculum spp.), with methanogenic archaea (Zengler et al., 1999; Siddique et al., 2012). For example, Methanosaeta spp. and Methanoculleus spp. have been repeatedly detected in methanogenic hydrocarbondegrading enrichment cultures (Siddique et al., 2006, 2011; Cheng et al., 2013). For in situ identification and quantification of methanogens in the SOFT core methanogenic zone we applied probe MS1414 targeting Methanosarcina, Methanococcoides, Methanohalophilus, and Methanolobus. Cell numbers were highest with $5.7 \times 10^{6}$ cells ml ${ }^{-1}(2 \%$ of total cells $)$ at the depth of $9 \mathrm{~cm}$ (Figure $4 \mathbf{F}$ ) where maximum methane increase was observed. Although hydrocarbon-degradation by Methanosarcina spp., which are the dominant methanogens in this study, has not been reported yet, and although detected Methanosarcina cells were not physically attached to any other cell, we hypothesize a contribution of this group to observed methanogenic hydrocarbon-degradation due to their specific increase in cell numbers in the methanogenic zone. The well-known bacterial partners such as Syntrophus or Desulfotomaculum were absent from the dataset. Only sporadically, Smithella sequences $(n=2$ at $13 \mathrm{~cm}$ depth) were found. Syntrophic growth of Methanosarcina has been described for an association with Geobacter spp. and depends on interspecies electron transfer (Rotaru et al., 2014), thus also allowing the speculation about hydrocarbon-degradation with a yet unknown bacterial partner.

\section{Anaerobic Alkane-Degrading Community Based on masD Gene Diversity}

The microbial community that activates alkanes by fumarate addition was studied by cloning of mas $D$ genes from selected SOFT core sediment layers that showed the highest sulfate reduction activity. Bss that activate aromatic compounds were not matched by the used primer pair. Considering the threshold for MasD species level of $96 \%$ amino acid identity recently defined by Stagars et al. (2016), a total of 16 species-level OTU 0.96 were retrieved after sequencing of 717 mas D-carrying clones. From untreated sediments, mas $D$ could not be amplified. Library coverage was $>96.8 \%$ for all samples. With inverse Simpson values of close to 1 (1.0-2.3), diversity of MasD was very low in SOFT core sediments (Table 1). As comparison, the
MasD diversity was even lower than in 12 globally distributed hydrocarbon seep sites for which inverse Simpson values of 3-9 were reported (Stagars et al., 2016).

MasD OTU $\mathrm{T}_{0.96}$ were widely distributed over the phylogenetic tree suggesting the presence of diverse anaerobic alkanedegrading bacteria in the sulfate reduction zone of SOFT sediments (Figure 5). However, two $\mathrm{MasD} \mathrm{OTU}_{0.96}$, i.e., MasD_OTU1 and OTU2, contained 97\% (571 sequences and 122 sequences) of all retrieved MasD sequences. They were both assigned to a bigger cluster that comprised Desulfothermus naphthae str. Td-3, a mid-chain $n$-alkane $\left(\mathrm{C}_{6}-\right.$ $\mathrm{C}_{16}$ )-degrading sulfate-reducing bacterium isolated from oily Guaymas Basin sediments (Rueter et al., 1994) as the only cultivated representative. OTU1 and OTU2 were most closely affiliated to a sequence from a butane enrichment from Amon mud volcano seep sediments (Kleindienst et al., 2014) and to a clone sequence from production water from a Chinese oil reservoir (Bian et al., 2014; database release). Our CARD-FISH data pointed to a response of SCA1/BuS5 on the simulated petroleum seepage. BuS5-related MasD sequences, however, were not found. This is most likely caused by substantial primer mispairing: The forward primers had 11 (7757f1-f2, 22mer) and 13 (7766f, 23mer) mismatches, respectively, to the BuS5-masD sequence retrieved from the genome (JGI gene ID 2513990058). Our MasD data support the recent findings by Stagars et al. (2016) who detected a total of 420 MasD-carrying species in 12 different hydrocarbon seep environments of which only few were abundant, cosmopolitan alkane degraders but many were specialized taxa across many different environments. It also matches our findings that short-chain alkane-degrading group SCA1 and long-chain alkane-degrading group LCA2 were the only taxa identified, which responded to simulated petroleum seepage by an increase of their cell numbers suggesting that we likely have identified the key alkane-degrading SRB in Caspian Sea sediments.

\section{CONCLUSION}

By molecular comparison of microbial communities in Caspian Sea sediments before and after controlled petroleum seepage, specific SRB and methanogenic archaea were identified who are likely responsible for the observed decrease in aliphatic hydrocarbon concentration. Although no aliphatic hydrocarbons could be detected in untreated Caspian Sea sediment, this study demonstrates the intrinsic potential for alkane degradation in the microbial community most likely due to a history of nearby hydrocarbon seepage. This study further suggests that identified SRB, such as members of the clades SCA1, LCA2, Desulfobacula, and Cyhx, are likely responsible for hydrocarbon degradation under close-to-in situ conditions. For some groups, cultivation has already been successful (BuS5, Kniemeyer et al., 2007); Desulfobacula (Rabus et al., 1993; Heider et al., 1998), and others have been enriched (clade Cyhx). Similar to aerobic hydrocarbon degradation in the water column, for example after the Deepwater Horizon accident, where gammaproteobacterial Oceaniserpentilla, Colwellia, or Cycloclasticus dominated in the 
hydrocarbon plume (Kleindienst et al., 2016), the major part of anaerobic hydrocarbon degradation is mediated by few groups of microbes specialized on the degradation of a specific hydrocarbon type: SCA1 is suggested to be likely responsible for propane and butane degradation [maybe together with the $\mathrm{C}_{2}-\mathrm{C}_{4}$ short-chain alkane-degrading group described by Adams et al. (2013)], LCA2 is suggested to be involved in mid- to long-chain alkane degradation, membes of clade Cyhx are suggested to be responsible for cycloalkanes, pentane, and hexane degradation, relatives of Desulfobacula are suggested as consumers of aromatic compounds and archaea of the genus Methanosarcina might be responsible for syntrophic methanogenic long-chain alkane degradation. Isolation attempts, metatranscriptomic and metagenomic approaches as well as single cell analyses of probe-targeted cells will help to get a deeper understanding of the ecophysiology of these clades and their suggested role in anaerobic hydrocarbon degradation.

\section{AUTHOR CONTRIBUTIONS}

KK, TT, and RA designed the study. SM and TT planned and conducted the SOFT experiment. SM did the field sampling and sulfate reduction measurements. MS processed tag sequencing data, analyzed the microbial diversity, constructed masD gene libraries and performed phylogenetic analysis of MasD. KK performed CARD-FISH experiments and cell counting as well as phylogenetic analysis of $16 \mathrm{~S}$ rRNA genes from hydrocarbon degraders. MS, TT, RA, and KK wrote the manuscript with input from SM.

\section{REFERENCES}

Acosta-González, A., Rosselló-Móra, R., and Marqués, S. (2013). Characterization of the anaerobic microbial community in oil-polluted subtidal sediments: aromatic biodegradation potential after the Prestige oil spill. Environ. Microbiol. 15, 77-92. doi: 10.1111/j.1462-2920.2012.02782.x

Adams, M. M., Hoarfrost, A. L., Bose, A., Joye, S. B., and Girguis, P. R. (2013). Anaerobic oxidation of short-chain alkanes in hydrothermal sediments: potential influences on sulfur cycling and microbial diversity. Front. Microbiol. 4:110. doi: $10.3389 /$ fmicb. 2013.00110

Aeckersberg, F., Bak, F., and Widdel, F. (1991). Anaerobic oxidation of saturatedhydrocarbons to $\mathrm{CO} 2$ by a new type of sulfate-reducing bacterium. Arch. Microbiol. 156, 5-14. doi: 10.1007/BF00418180

Akper, A. (2012). Mud volcanoes in the South Caspian basin: nature and estimated depth of its products. Nat. Sci. 4, 445-453.

Atlas, R. M. (1981). Microbial degradation of petroleum hydrocarbons: an environmental perspective. Microbiol. Rev. 45, 180-209.

Atlas, R. M., and Hazen, T. C. (2011). Oil biodegradation and bioremediation: a tale of the two worst spills in U.S. history. Environ. Sci. Technol. 45, 6709-6715. doi: 10.1021/es2013227

Bak, F., and Widdel, F. (1986). Anaerobic degradation of phenol and phenol derivatives by Desulfobacterium phenolicum sp. nov. Arch. Microbiol. 146, 177-180. doi: 10.1007/BF00402347

Berdugo-Clavijo, C., and Gieg, L. M. (2014). Conversion of crude oil to methane by a microbial consortium enriched from oil reservoir production waters. Front. Microbiol. 5:197. doi: 10.3389/fmicb.2014.00197

Bian, X.-Y., Maurice Mbadinga, S., Liu, Y.-F., Yang, S.-Z., Liu, J.-F., Ye, R.-Q., et al. (2015). Insights into the anaerobic biodegradation pathway of $n$-alkanes in oil reservoirs by detection of signature metabolites. Sci. Rep. 5:9801.

\section{FUNDING}

This work was funded by the Deutsche Forschungsgemeinschaft (SPP1319) and DEA Deutsche Erdöl AG. Further support was provided by the Max Planck Society, Germany.

\section{ACKNOWLEDGMENTS}

The Geological Institute of Azerbaijan is thanked for their collaboration as well as M. Schmidt and P. Felden for their support during field sampling. P. Steeb is acknowledged for advising the development of the SOFT system. We would also like to thank the Technical and Logistic Center (TLZ) of GEOMAR for their technical support in building the SOFT system, especially D. Wehrend, A. Petersen, and S. Sturm. We also thank B. Domeyer, A. Bleyer, and R. Suberg for their support in geochemical analyses and S. Bold and D. Ozod-Seradj for helping during the termination of the SOFT experiment. We thank G. Reintjes for help with IonTorrent sequencing and D. Probandt for help with Illumina sequence analysis. K. Büttner is acknowledged for excellent technical assistance.

\section{SUPPLEMENTARY MATERIAL}

The Supplementary Material for this article can be found online at: http://journal.frontiersin.org/article/10.3389/fmicb. 2017.00764/full\#supplementary-material

Bray, J. R., and Curtis, J. T. (1957). An Ordination of the upland forest communities of Southern Wisconsin. Ecol. Monogr. 27, 325-349. doi: 10.2307/1942268

Callaghan, A. V. (2013). Enzymes involved in the anaerobic oxidation of $n$-alkanes: from methane to long-chain paraffins. Front. Microbiol. 4:89. doi: 10.3389/ fmicb.2013.00089

Callaghan, A. V., Wawrik, B., Ní Chadhain, S. M., Young, L. Y., and Zylstra, G. J. (2008). Anaerobic alkane-degrading strain AK-01 contains two alkylsuccinate synthase genes. Biochem. Biophys. Res. Commun. 366, 142-148. doi: 10.1016/j. bbrc.2007.11.094

Chang, Y. T., Lee, J. F., Chao, H. P., and Liao, W. L. (2006). Bacterial community changes with $\mathrm{N}$ '-N' dimethylforamide (DMF) additives during polycyclic aromatic hydrocarbons (PAH) biodegardation. Environ. Technol. 27, 1-14. doi: 10.1080/09593332708618613

Chao, A. (1984). Nonparametric estimation of the number of classes in a population. Scand. J. Stat. 11, 265-270.

Cheng, L., Rui, J., Li, Q., Zhang, H., and Lu, Y. (2013). Enrichment and dynamics of novel syntrophs in a methanogenic hexadecane-degrading culture from a Chinese oilfield. FEMS Microbiol. Ecol. 83, 757-766. doi: 10.1111/1574-6941. 12031

Chung, W. K., and King, G. M. (2001). Isolation, characterization, and polyaromatic hydrocarbon degradation potential of aerobic bacteria from marine macrofaunal burrow sediments and description of Lutibacterium anuloederans gen. nov., sp. nov., and Cycloclasticus spirillensus sp. nov. Appl. Environ. Microbiol. 67, 5585-5592.

Coulon, F., Chronopoulou, P.-M., Fahy, A., Païssé, S., Goñi-Urriza, M., Peperzak, L., et al. (2012). Central role of dynamic tidal biofilms dominated by aerobic hydrocarbonoclastic bacteria and diatoms in the biodegradation of hydrocarbons in coastal mudflats. Appl. Environ. Microbiol. 78, 3638-3648. doi: 10.1128/AEM.00072-12 
Cui, Z., Lai, Q., Dong, C., and Shao, Z. (2008). Biodiversity of polycyclic aromatic hydrocarbon-degrading bacteria from deep sea sediments of the Middle Atlantic Ridge. Environ. Microbiol. 10, 2138-2149. doi: 10.1111/j.1462-2920. 2008.01637.x

Cui, Z., Xu, G., Gao, W., Li, Q., Yang, B., Yang, G., et al. (2014). Isolation and characterization of Cycloclasticus strains from Yellow Sea sediments and biodegradation of pyrene and fluoranthene by their syntrophic association with Marinobacter strains. Int. Biodeter. Biodegr. 91, 45-51. doi: 10.1016/j.ibiod. 2014.03.005

Dong, C., Bai, X., Sheng, H., Jiao, L., Zhou, H., and Shao, Z. (2015). Distribution of PAHs and the PAH-degrading bacteria in the deep-sea sediments of the highlatitude Arctic Ocean. Biogeosciences 12, 2163-2177. doi: 10.5194/bg-12-21632015

Dumont, H. J. (1995). Ecocide in the Caspian Sea. Nature 377, 673-674. doi: $10.1038 / 377673 \mathrm{a} 0$

Dyksma, S., Bischof, K., Fuchs, B. M., Hoffmann, K., Meier, D., Meyerdierks, A., et al. (2016). Ubiquitous Gammaproteobacteria dominate dark carbon fixation in coastal sediments. ISME J. 10, 1939-1953. doi: 10.1038/ismej.2015.257

Dyksterhouse, S. E., Gray, J. P., Herwig, R. P., Lara, J. C., and Staley, J. T. (1995). Cycloclasticus pugetii gen. nov, sp. nov., an aromatic hydrocarbondegrading bacterium from marine sediments. Int. J. Syst. Bacteriol. 45, 116-123. doi: 10.1099/00207713-45-1-116

Edgar, R. C., Haas, B. J., Clemente, J. C., Quince, C., and Knight, R. (2011). UCHIME improves sensitivity and speed of chimera detection. Bioinformatics 27, 2194-2200. doi: 10.1093/bioinformatics/btr381

Effimoff, I. (2000). The oil and gas resource base of the Caspian region. J. Pet. Sci. Eng. 28, 157-159. doi: 10.1016/S0920-4105(00)00075-9

Embree, M., Nagarajan, H., Movahedi, N., Chitsaz, H., and Zengler, K. (2014). Single-cell genome and metatranscriptome sequencing reveal metabolic interactions of an alkane-degrading methanogenic community. ISME J. 8, 757-767. doi: 10.1038/ismej.2013.187

Ferrer, M., Guazzaroni, M.-E., Richter, M., García-Salamanca, A., Yarza, P., SuárezSuárez, A., et al. (2011). Taxonomic and functional metagenomic profiling of the microbial community in the anoxic sediment of a sub-saline shallow lake (Laguna de Carrizo, central Spain). Microb. Ecol. 62, 824-837. doi: 10.1007/ s00248-011-9903-y

Geiselbrecht, A. D., Hedlund, B. P., Tichi, M. A., and Staley, J. T. (1998). Isolation of marine polycyclic aromatic hydrocarbon (PAH)-degrading Cycloclasticus strains from the Gulf of Mexico and comparison of their PAH degradation ability with that of Puget Sound Cycloclasticus strains. Appl. Environ. Microbiol. 64, 4703-4710.

Good, I. J. (1953). The population frequencies of species and the estimation of population parameters. Biometrika 40, 237-264. doi: 10.1093/biomet/40. 3-4.237

Gower, J. C. (1975). Generalized procrustes analysis. Psychometrika 40, 33-51. doi: 10.1007/BF02291478

Grossi, V., Cravo-Laureau, C., Guyoneaud, R., Ranchou-Peyruse, A., and Hirschler-Rea, A. (2008). Metabolism of n-alkanes and n-alkeries by anaerobic bacteria: a summary. Org. Geochem. 39, 1197-1203. doi: 10.1016/j.orggeochem. 2008.02.010

Grundmann, O., Behrends, A., Rabus, R., Amann, J., Halder, T., Heider, J., et al. (2008). Genes encoding the candidate enzyme for anaerobic activation of $n$-alkanes in the denitrifying bacterium, strain HxN1. Environ. Microbiol. 10, 376-385. doi: 10.1111/j.1462-2920.2007.01458.x

Gutierrez, T., Biddle, J. F., Teske, A., and Aitken, M. (2015). Cultivationdependent and cultivation-independent characterisation of hydrocarbondegrading bacteria in Guaymas Basin sediments. Front. Microbiol. 6:695. doi: $10.3389 /$ fmicb. 2015.00695

Hassanshahian, M. (2014). The effects of crude oil on marine microbial communities in sediments from the Persian Gulf and the Caspian Sea: a microcosm experiment. Int. J. Adv. Biol. Biomed. Res. 2, 1-17.

Hassanshahian, M., Emtiazi, G., and Cappello, S. (2012). Isolation and characterization of crude-oil-degrading bacteria from the Persian Gulf and the Caspian Sea. Mar. Polut. Bull. 64, 7-12. doi: 10.1016/j.marpolbul.2011.11.006

Hassanshahian, M., Emtiazi, G., Kermanshahi, R. K., and Cappello, S. (2010). Comparison of oil degrading microbial communities in sediments from the Persian Gulf and Caspian Sea. Soil Sediment Contam. 19, 277-291. doi: 10.1080/ 15320381003695215
Head, I. M., Jones, D. M., and Larter, S. R. (2003). Biological activity in the deep subsurface and the origin of heavy oil. Nature 426, 344-352. doi: 10.1038/ nature 02134

Heider, J., and Schühle, K. (2013). "Anaerobic biodegradation of hydrocarbons including methane," in The Prokaryotes, eds E. Rosenberg, E. F. Delong, S. Lory, E. Stackebrandt, and F. Thompson (Berlin: Springer), 605-634.

Heider, J., Spormann, A. M., Beller, H. R., and Widdel, F. (1998). Anaerobic bacterial metabolism of hydrocarbons. FEMS Microbiol. Rev. 22, 459-473. doi: 10.1111/j.1574-6976.1998.tb00381.x

Herlemann, D. P. R., Labrenz, M., Jurgens, K., Bertilsson, S., Waniek, J. J., and Andersson, A. F. (2011). Transitions in bacterial communities along the 2000 $\mathrm{km}$ salinity gradient of the Baltic Sea. ISME J. 5, 1571-1579. doi: 10.1038/ismej. 2011.41

Hill, T. C. J., Walsh, K. A., Harris, J. A., and Moffett, B. F. (2003). Using ecological diversity measures with bacterial communities. FEMS Microbiol. Ecol. 43, 1-11. doi: 10.1111/j.1574-6941.2003.tb01040.x

Jaekel, U. (2011). Anaerobic Oxidation of Short-Chain and Cyclic Alkanes by Sulfate-Reducing Bacteria. Doctoral dissertation, University Bremen, Bremen.

Jaekel, U., Musat, N., Adam, B., Kuypers, M., Grundmann, O., and Musat, F. (2013). Anaerobic degradation of propane and butane by sulfate-reducing bacteria enriched from marine hydrocarbon cold seeps. ISME J. 7, 885-895. doi: 10.1038/ismej.2012.159

Jaekel, U., Zedelius, J., Wilkes, H., and Musat, F. (2015). Anaerobic degradation of cyclohexane by sulfate-reducing bacteria from hydrocarbon-contaminated marine sediments. Front. Microbiol. 6:116. doi: 10.3389/fmicb.2015.00116

Johnson, J. M., Wawrik, B., Isom, C., Boling, W. B., and Callaghan, A. V. (2015). Interrogation of Chesapeake Bay sediment microbial communities for intrinsic alkane-utilizing potential under anaerobic conditions. FEMS Microbiol. Ecol. 91, 1-14. doi: 10.1093/femsec/fiu035

Jones, D. M., Head, I. M., Gray, N. D., Adams, J. J., Rowan, A. K., Aitken, C. M., et al. (2008). Crude-oil biodegradation via methanogenesis in subsurface petroleum reservoirs. Nature 451, 176-180. doi: 10.1038/nature06484

Karpinsky, M. G. (1992). Aspects of the Caspian Sea benthic ecosystem. Mar. Pollut. Bull. 24, 384-389. doi: 10.1016/0025-326X(92)90498-U

Kim, S.-J., and Kwon, K. (2010). "Marine, hydrocarbon-degrading Alphaproteobacteria," in Handbook of Hydrocarbon and Lipid Microbiology, eds K. N. Timmis, T. Mcgenity, J. R. Van Der Meer, and V. De Lorenzo (Berlin: Springer), 1707-1714.

Kimes, N. E., Callaghan, A. V., Aktas, D. F., Smith, W. L., Sunner, J., Golding, B. T., et al. (2013). Metagenomic analysis and metabolite profiling of deep-sea sediments from the Gulf of Mexico following the Deepwater Horizon oil spill. Front. Microbiol. 4:50. doi: 10.3389/fmicb.2013.00050

Kimes, N. E., Callaghan, A. V., Suflita, J. M., and Morris, P. J. (2014). Microbial transformation of the Deepwater Horizon oil spill - past, present, and future perspectives. Front. Microbiol. 5:603. doi: 10.3389/fmicb.2014.00603

Kleindienst, S., Grim, S., Sogin, M., Bracco, A., Crespo-Medina, M., and Joye, S. B. (2016). Diverse, rare microbial taxa responded to the Deepwater Horizon deep-sea hydrocarbon plume. ISME J. 10, 400-415. doi: 10.1038/ismej. 2015.121

Kleindienst, S., Herbst, F.-A., Stagars, M., Von Netzer, F., Von Bergen, M., Seifert, J., et al. (2014). Diverse sulfate-reducing bacteria of the Desulfosarcina/Desulfococcus clade are the key alkane degraders at marine seeps. ISME J. 8, 2029-2044. doi: 10.1038/ismej.2014.51

Kleindienst, S., Ramette, A., Amann, R., and Knittel, K. (2012). Distribution and in situ abundance of sulfate-reducing bacteria in diverse marine hydrocarbon seep sediments. Environ. Microbiol. 14, 2689-2710. doi: 10.1111/j.1462-2920. 2012.02832.x

Kniemeyer, O., Musat, F., Sievert, S. M., Knittel, K., Wilkes, H., Blumenberg, M., et al. (2007). Anaerobic oxidation of short-chain hydrocarbons by marine sulphate-reducing bacteria. Nature 449, 898-910. doi: 10.1038/nature06200

Knittel, K., Boetius, A., Lemke, A., Eilers, H., Lochte, K., Pfannkuche, O., et al. (2003). Activity, distribution, and diversity of sulfate reducers and other bacteria in sediments above gas hydrate (Cascadia margin. Oregon). Geomicrobiol. J. 20, 269-294. doi: 10.1080/01490450303896

Könneke, M., Schubert, D. M., Brown, P. C., Hügler, M., Standfest, S., Schwander, T., et al. (2014). Ammonia-oxidizing archaea use the most energyefficient aerobic pathway for $\mathrm{CO}(2)$ fixation. Proc. Natl. Acad. Sci. U.S.A. 111, 8239-8244. doi: 10.1073/pnas.1402028111 
Kozich, J. J., Westcott, S. L., Baxter, N. T., Highlander, S. K., and Schloss, P. D. (2013). Development of a dual-index sequencing strategy and curation pipeline for analyzing amplicon sequence data on the MiSeq Illumina sequencing platform. Appl. Environ. Microbiol. 79, 5112-5120. doi: 10.1128/AEM.01043-13

Kruskal, J. B. (1964). Nonmetric multidimensional scaling: a numerical method. Psychometrika 29, 115-129. doi: 10.1007/BF02289694

Kuever, J., Könneke, M., Galushko, A., and Drzyzga, O. (2001). Reclassification of Desulfobacterium phenolicum as Desulfobacula phenolica comb. nov. and description of strain SaxT as Desulfotignum balticum gen. nov., sp. nov. Int. J. Syst. Evol. Microbiol. 51, 171-177. doi: 10.1099/00207713-51-1-171

Laso-Pérez, R., Wegener, G., Knittel, K., Widdel, F., Harding, K. J., Krukenberg, V., et al. (2016). Thermophilic archaea activate butane via alkyl-coenzyme M formation. Nature 539, 396-401. doi: 10.1038/nature20152

Leahy, J. G., and Colwell, R. R. (1990). Microbial degradation of hydrocarbons in the environment. Microbiol. Rev. 54, 305-315.

Mahmoudi, N., Robeson, M. S., Castro, H. F., Fortney, J. L., Techtmann, S. M., Joyner, D. C., et al. (2015). Microbial community composition and diversity in Caspian Sea sediments. FEMS Microbiol. Ecol. 91, 1-11. doi: 10.1093/femsec/ fiu013

Massana, R., Murray, A. E., Preston, C. M., and Delong, E. F. (1997). Vertical distribution and phylogenetic characterization of marine planktonic archaea in the Santa Barbara Channel. Appl. Environ. Microbiol. 63, 50-56.

Mbadinga, S. M., Li, K. P., Zhou, L., Wang, L. Y., Yang, S. Z., Liu, J. F., et al. (2012). Analysis of alkane-dependent methanogenic community derived from production water of a high-temperature petroleum reservoir. Appl. Microbiol. Biotechnol. 96, 531-542. doi: 10.1007/s00253-011-3828-8

Mbadinga, S. M., Wang, L.-Y., Zhou, L., Liu, J.-F., Gu, J.-D., and Mu, B.-Z. (2011). Microbial communities involved in anaerobic degradation of alkanes. Int. Biodeter. Biodegr. 65, 1-13. doi: 10.1016/j.ibiod.2010.11.009

McKew, B. A., Coulon, F., Osborn, A. M., Timmis, K. N., and Mcgenity, T. J. (2007). Determining the identity and roles of oil-metabolizing marine bacteria from the Thames estuary. UK. Environ. Microbiol. 9, 165-176. doi: 10.1111/j.1462-2920. 2006.01125.x

Millero, F. J., and Chetirkin, P. V. (1980). The density of Caspian Sea waters. Deep Sea Res. 27, 265-271. doi: 10.1016/0198-0149(80)90017-5

Morasch, B., Schink, B., Tebbe, C. C., and Meckenstock, R. U. (2004). Degradation of o-xylene and m-xylene by a novel sulfate-reducer belonging to the genus Desulfotomaculum. Arch. Microbiol. 181, 407-417. doi: 10.1007/s00203-0040672-6

Musat, F. (2015). The anaerobic degradation of gaseous, nonmethane alkanes from in situ processes to microorganisms. Comput. Struct. Biotechnol. J. 13, 222-228. doi: 10.1016/j.csbj.2015.03.002

Mußmann, M., Dyksma, S., Probandt, D., Virant, D., Ovanesov, K., and Littmann, S. (2015). "Ecology and ecogenomics of uncultured sulfate-reducing bacteria ubiquitous and abundant in marine sediments," in Proceedings of the EMBO Workshop on Microbial Sulfur Metabolism, Helsingor.

Myhr, S., Lillebo, B. L. P., Sunde, E., Beeder, J., and Torsvik, T. (2002). Inhibition of microbial $\mathrm{H} 2 \mathrm{~S}$ production in an oil reservoir model column by nitrate injection. Appl. Microbiol. Biotechnol. 58, 400-408. doi: 10.1007/s00253-001-0881-8

Niepceron, M., Portet-Koltalo, F., Merlin, C., Motelay-Massei, A., Barray, S., and Bodilis, J. (2010). Both Cycloclasticus spp. and Pseudomonas spp. as PAHdegrading bacteria in the Seine estuary (France). FEMS Microbiol. Ecol. 71, 137-147. doi: 10.1111/j.1574-6941.2009.00788.x

Pernthaler, A., Pernthaler, J., and Amann, R. (2002). Fluorescence in situ hybridization and catalyzed reporter deposition for the identification of marine bacteria. Appl. Environ. Microbiol. 68, 3094-3101. doi: 10.1128/AEM.68.6.30943101.2002

Quast, C., Pruesse, E., Yilmaz, P., Gerken, J., Schweer, T., Yarza, P., et al. (2013). The SILVA ribosomal RNA gene database project: improved data processing and web-based tools. Nucleic Acids Res. 41, D590-D596. doi: 10.1093/nar/gks1219

Rabus, R., Boll, M., Heider, J., Meckenstock, R. U., Buckel, W., Einsle, O., et al. (2016). Anaerobic microbial degradation of hydrocarbons: from enzymatic reactions to the environment. J. Mol. Microbiol. Biotechnol. 26, 5-28. doi: $10.1159 / 000443997$

Rabus, R., Nordhaus, R., Ludwig, W., and Widdel, F. (1993). Complete oxidation of toluene under strictly anoxic conditions by a new sulfate-reducing bacterium. Appl. Environ. Microbiol. 59, 1444-1451.
Ravenschlag, K., Sahm, K., Pernthaler, J., and Amann, R. (1999). High bacterial diversity in permanently cold marine sediments. Appl. Environ. Microbiol. 65, 3982-3989.

Rotaru, A.-E., Shrestha, P. M., Liu, F., Markovaite, B., Chen, S., Nevin, K. P., et al. (2014). Direct interspecies electron transfer between Geobacter metallireducens and Methanosarcina barkeri. Appl. Environ. Microbiol. 80, 4599-4605. doi: 10.1128/AEM.00895-14

Rueter, P., Rabus, R., Wilkest, H., Aeckersberg, F., Rainey, F. A., Jannasch, H. W., et al. (1994). Anaerobic oxidation of hydrocarbons in crude oil by new types of sulphate-reducing bacteria. Nature 372, 455-458. doi: 10.1038/372455a0

Ruff, S. E., Biddle, J. F., Teske, A. P., Knittel, K., Boetius, A., and Ramette, A. (2015). Global dispersion and local diversification of the methane seep microbiome. Proc. Natl. Acad. Sci. U.S.A. 112, 4015-4020. doi: 10.1073/pnas.1421 865112

Saw, J. H., Spang, A., Zaremba-Niedzwiedzka, K., Juzokaite, L., Dodsworth, J. A., Murugapiran, S. K., et al. (2015). Exploring microbial dark matter to resolve the deep archaeal ancestry of eukaryotes. Philos. Trans. R. Soc. Lond. B Biol. Sci. 370:20140328. doi: 10.1098/rstb.2014.0328

Schloss, P. D., Westcott, S. L., Ryabin, T., Hall, J. R., Hartmann, M., Hollister, E. B., et al. (2009). Introducing mothur: open-source, platform-independent, community-supported software for describing and comparing microbial communities. Appl. Environ. Microbiol. 75, 7537-7541. doi: 10.1128/AEM. 01541-09

Schreiber, L., Holler, T., Knittel, K., Meyerdierks, A., and Amann, R. (2010). Identification of the dominant sulfate-reducing bacterial partner of anaerobic methanotrophs of the ANME-2 clade. Environ. Microbiol. 12, 2327-2340. doi: $10.1111 / j .1462-2920.2010 .02275 . x$

Siddique, T., Fedorak, P. M., and Foght, J. M. (2006). Biodegradation of shortchain n-alkanes in oil sands tailings under methanogenic conditions. Environ. Sci. Technol. 40, 5459-5464. doi: 10.1021/es060993m

Siddique, T., Penner, T., Klassen, J., Nesbø, C., and Foght, J. M. (2012). Microbial communities involved in methane production from hydrocarbons in oil sands tailings. Environ. Sci. Technol. 46, 9802-9810. doi: 10.1021/es302202c

Siddique, T., Penner, T., Semple, K., and Foght, J. M. (2011). Anaerobic biodegradation of longer-chain $n$-alkanes coupled to methane production in oil sands tailings. Environ. Sci. Technol. 45, 5892-5899. doi: 10.1021/es200649t

Sørensen, K. B., and Teske, A. (2006). Stratified communities of active archaea in deep marine subsurface sediments. Appl. Environ. Microbiol. 72, 4596-4603. doi: 10.1128/AEM.00562-06

Stagars, M., Ruff, E., Amann, R., and Knittel, K. (2016). High diversity of anaerobic alkane-degrading microbial communities in marine seep sediments based on their (1-methylalkyl)succinate synthase genes. Front. Microbiol. 6:1511. doi: 10.3389/fmicb.2015.01511

von Netzer, F., Pilloni, G., Kleindienst, S., Krüger, M., Knittel, K., Gründger, F., et al. (2013). Enhanced gene detection assays for fumarate-adding enzymes allow uncovering of anaerobic hydrocarbon degraders in terrestrial and marine systems. Appl. Environ. Microbiol. 79, 543-552. doi: 10.1128/AEM. 02362-12

Yarza, P., Yilmaz, P., Pruesse, E., Glockner, F. O., Ludwig, W., Schleifer, K.-H., et al. (2014). Uniting the classification of cultured and uncultured bacteria and archaea using 16S rRNA gene sequences. Nat. Rev. Microbiol. 12, 635-645. doi: $10.1038 /$ nrmicro3330

Zengler, K., Richnow, H. H., Rosselló-Móra, R., Michaelis, W., and Widdel, F. (1999). Methane formation from long-chain alkanes by anaerobic microorganisms. Nature 401, 266-269. doi: 10.1038/45777

Conflict of Interest Statement: The authors declare that the research was conducted in the absence of any commercial or financial relationships that could be construed as a potential conflict of interest.

Copyright (c) 2017 Stagars, Mishra, Treude, Amann and Knittel. This is an openaccess article distributed under the terms of the Creative Commons Attribution License (CC BY). The use, distribution or reproduction in other forums is permitted, provided the original author(s) or licensor are credited and that the original publication in this journal is cited, in accordance with accepted academic practice. No use, distribution or reproduction is permitted which does not comply with these terms. 